\title{
DiAgNOZY I POSTULATY \\ III I IV MaŁego Forum EduKaCyjnego TLiAM
}

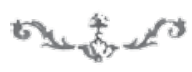

$\mathrm{W}$ ZAINICJOWANYCH i prowadzonych przez wyżej podpisaną (wiceprezes TLiAM, prof. dr hab. Lidię Wiśniewską) spotkaniach III i IV Małego Forum Edukacyjnego (Warszawa 9-10 maja i 20-21 czerwca 2015), mających na celu wyartykułowanie podstawowych kwestii, jakie Towarzystwo Literackie, zobowiązane do tego głosami swych członków na poprzednim Zjeździe, zamierza podnieść - tym razem podczas II Kongresu Dydaktyki Polonistycznej w Katowicach - udział wzięli nauczyciele i wykładowcy wyższych uczelni (wymieniając alfabetycznie): prof. dr hab. Tadeusz Budrewicz (UP im. KEN), prof. UP im. KEN dr hab. Zofia Budrewicz, prof. UKSW dr hab. Tomasz Chachulski, dr Mirosław Gołuński (UKW), mgr Karol Jaworski (V Liceum Ogólnokształcące im. Księcia Józefa Poniatowskiego w Warszawie), dr Marta Kładź-Kocot, prof. dr hab. Teresa Kostkiewiczowa (IBL PAN), mgr Anna Nakielska-Kowalska (Zespół Szkół Ogólnokształcących nr 6 w Bydgoszczy), mgr Katarzyna Porembska (LXIV Liceum Ogólnokształcące im. Stanisława Ignacego Witkiewicza w Warszawie), prof. UW dr hab. Ewa Szczęsna, prof. UKSW dr hab. Magdalena Saganiak, prof. dr hab. Tadeusz Sławek (UŚ), dr Anna Ślósarz (UP im. KEN), prof. UR dr hab. Marek Stanisz, mgr Mirosław Skrzypczyk (Zespół Szkół w Szczekocinach), mgr Marek Urbanowicz (I Liceum Ogólnokształcące im. Marii Konopnickiej w Suwałkach), dr Dorota Utracka (Akademia Humanistyczno-Ekonomiczna w Łodzi), mgr Joanna Zaremba (V Liceum Ogólnokształcące im. Księcia Józefa Poniatowskiego w Warszawie, mgr Daniel Zych (LXIV Liceum Ogólnokształcące im. Stanisława Ignacego Witkiewicza w Warszawie). 
Jeśli chodzi o kwestię realizacji postulatów z poprzednich spotkań, zdania były podzielone: nieodosobniony brak usatysfakcjonowania wyżej podpisanej zderzał się z przekonaniem, że i tak w ostatnich latach nie zrobiono by więcej, niż zdolny był zrobić dla poprawy sytuacji w szkolnictwie I Kongres Dydaktyki Polonistycznej w Krakowie (20-23 listopada 2013) oraz działania organizatorów podejmowane po jego zakończeniu. Zgodziliśmy się natomiast, że Towarzystwo Literackie nadal powinno głośno wyrażać swoje zdanie dotyczące istniejącej sytuacji i domagać się konkretnych posunięć zmierzających nie do pozorowanej, ale do istotnej zmiany, a może raczej - „porewolucyjnej” restauracji (co nie jest równoznaczne $\mathrm{z}$ w ogóle nieskorygowanym powrotem do stanu sprzed reform) podstawowych zasad pozwalających szkolnictwu na realizowanie jego zadań konstytutywnych, a nie tyleż marginalnych, co marginalizujących oraz instrumentalizujących system edukacji, przez to zaś prowadzących do destrukcji zarówno merytoryczności i fachowości, jak i odpowiedzialności za jego stan.

Odpowiedzialność bowiem wiąże się z określonymi prawami, a przede wszystkim z wolnością działania, tymczasem, co dobitnie wyraził prof. Tadeusz Sławek, stwarzane dziś pozory wolności (poprzez wybór możliwy tylko spośród tego, co jako „użyteczne” zdefiniuje technobiurokracja czerpiąca swą siłę z kultu produkcji i kapitału) skojarzone z nastawieniem na ilość oraz wciskaniem szkolnictwa w gorsety testów, pomiarów, audytów, grantów - generalnie zaś w schematyzację - prowadzi do dawania wykształcenia często noszącego jedynie jego wykształcenia (a podobnie, dodajmy, rzecz się ma też z wychowaniem w szkołach). Funkcjonujące na uczelniach sylabusy z ich abstrakcyjnymi i nader często zupełnie nonsensownie formułowanymi „efektami kształcenia”, z przedmiotami i umiejętnościami opatrzonymi symbolami niczym towary kodem kreskowym, znajdują swój początek w dwóch silnie przez ową biurokrację żywionych przeświadczeniach. Pierwsze z nich zakłada, że w związku z tym, iż zadaniem każdej szkoły jest „produkcja” i relacja świadczenia usług zachodząca między klientem a fachowcem, można przystąpić do zabiegów liczenia towarów, drugie - że wiedza jako towar musi zostać odpowiednio „wyłożona” - przez co jednak nie należy rozumieć bynajmniej sposobu i jakości wykładu (działalność nauczycielska w tej perspektywie jest praktycznie bez znaczenia), lecz to, jak tematy wykładów i obszary zagadnień zostaną udostępnione i zaprezentowane studentowi przez efektowne opakowanie, opatrzenie kodem i ustawienie niczym towaru na półkach wielkiego magazynu. Ta uwaga w znacznej mierze odnosi się też zresztą do szkolnictwa niższych szczebli.

Ponadto na wszystkich szczeblach zaobserwować można rosnące znaczenie „pedagogiki przyjemności” (w myśl której uczeń/student powinien dobrze 
się bawić i osiągnąć cel przy minimalnym wysiłku), stanowiącej w istocie narzędzie rozwijania konsumpcjonizmu, a występującej w powiązaniu z natrętnie wtłaczanym wszędzie pragmatyzmem wynikającym $z$ terroru rynku (tylko to ma być ważne, co przyda się na rynku pracy - jakby w istocie to, co się przyda, było możliwe do absolutnego zaprogramowania i przesądzenia).

Wszystko to razem wzięte sprawia, że tak fałszywie pojęta kultura edukacyjna w istocie pogrąża to, co najważniejsze: osobiste i osobowe zaangażowanie zarówno uczniów/studentów, jak i nauczycieli/wykładowców akademickich w proces kształcenia, czyli - zgodnie z najbardziej encyklopedycznym ujęciem - w ogół czynności i procesów umożliwiających uzyskanie przez tych pierwszych orientacji w otaczającej rzeczywistości przyrodniczej i społecznej, a zmierzających do możliwie wszechstronnego rozwoju osobowości i ogólnej sprawności umysłowej przy jednoczesnym kształtowaniu określonych uzdolnień i zainteresowań.

W dalszym ciągu nie zmienia się zatem nasze ogólne widzenie sytuacji, przedstawione przed poprzednim Kongresem ${ }^{1}$ i za marginalizujące rolę szkolnictwa na wszystkich stopniach uznajemy przeobrażanie go w rynek, a nauczycieli w sprzedawców z przygotowaniem marketingowym, zaś studentów, uczniów, rodziców - w klientów chętnie uczestniczących w nieustannych targach edukacyjnych. Jeśli bowiem podstawową rolą szkolnictwa jest kształcenie (i wychowywanie) młodych ludzi, oznacza to, że k a ż d a ze stron musi podjąć określony wysiłek zmierzający do (twórczego) przekazania lub - (twórczego) przyjęcia pewnych treści, pobudzenia umiejętności ich odczuwania i związanego z nimi myślenia bądź - wyrażania siebie i nawiązywania relacji interpersonalnych umożliwiających funkcjonowanie w społeczeństwie. Przy czym, jak się wydaje, na razie nie znaleziono bogatszego i bardziej giętkiego instrumentu służącego temu celowi niż język oraz szerszego zakresu niż kultura - a jedno i drugie stanowi przedmiot zainteresowania polonistów czy, szerzej rzecz ujmując, humanistów.

\section{ODPOWIEDZIALNOŚĆ W WARUNKACH SZKOŁY-MARKETU}

Wprowadzanie pojęć z zakresu rynku do szkolnictwa powoduje, jak obserwują doświadczeni nauczyciele ze znakomitej szkoły, mgr Katarzyna Porembska i mgr Daniel Zych, że uczniowie myślą pragmatycznie i głównie kalkulują, co „się opłaca”. Dr Dorota Utracka zauważa, że operując w szkole - podobnie jak na uczelni - systemem punktów jako odpowiedników pie- 
niędzy, nader często wykształca się zarówno w uczniach, jak i studentach (równie jak w rodzicach) myślenie i działanie wedle strategii: jak zdobyć najmniejszym nakładem sił (najmniejszym kosztem) najwięcej punktów (gratyfikacja), a nie - jak zdobyć najwięcej ugruntowanej wiedzy i umiejętności dzięki odpowiedniemu do tego nakładowi pracy. Bywa więc, że uczeń na przykład, nader ceniąc swój czas, odmawia wykonania jakiejś pracy, jeśli wartość potencjalnej gratyfikacji nie przekłada się na odpowiednią do jego oczekiwań tak zwaną średnią ważoną oceny, często wnosząc roszczenia co do wartości swej pracy i targuje się, jakby był na rynku: „Przygotuję (w domyśle: z pomocą nauczyciela) referat lub prezentację, jeśli będzie to liczone jako samodzielny projekt” (co należy rozumieć: „Zrobię coś, jeśli zamiast trzech punktów, które jest to warte, dostanę sześć punktów"). Stosując wymuszenia i manipulacje, opiera się na uzasadnionym skądinąd przekonaniu, że nauczyciel i tak nie ma prawdziwego prawa głosu, ponieważ ocenę wystawia się nie na podstawie istotnego wysiłku, ale punktów. Na próby zmotywowania do tego wysiłku odpowiada więc: „To pan/pani musi się starać, bo panu/pani za to płacą, a nam nie” - wiedząc, że sporne kwestie merytoryczne, dydaktyczne, a zwłaszcza pedagogiczne, rozstrzygane są w istocie przez nadzór pedagogiczny (urzędników), rodziców, wreszcie przez samych uczniów ponad głową nauczyciela - i zwykle na jego niekorzyść.

Co więcej, w ocenie nauczyciela, jak stwierdza dr Anna Ślósarz, pojawiają się mechanizmy działające na szkodę tych, którzy wymagają. W Okręgowej Komisji Egzaminacyjnej odwołanie się abiturienta od oceny niedostatecznej $\mathrm{z}$ ustnego egzaminu maturalnego $\mathrm{z}$ języka polskiego rozpatrywane bywa rutynowo na korzyść zdającego, często zresztą na podstawie opinii eksperta niepolonisty, który żąda od egzaminatorów szczegółowych wyjaśnień dotyczących prac komisji sformułowanych na piśmie. Wystawienie oceny niedostatecznej z ustnego egzaminu dojrzałości skutkuje w niektórych szkołach kierowanymi do dyrekcji prośbami kolejnych abiturientów o danie im możliwości zdawania przed inną komisją, a wymagający egzaminatorzy bywają w ten sposób pozbawiani prawa pełnienia obowiązków, czyli w praktyce - odwołani z funkcji.

Dr Mirosław Gołuński przypomina, że także w codziennej praktyce szkolnej postawienie jednej oceny niedostatecznej śród- lub końcoworocznej oznacza dwie stronice biurokratycznego wyjaśniania i skonstruowanie programu naprawczego przez nauczyciela; nic natomiast nie słychać o dwu stronicach wyjaśnienia i „programie naprawczym” ze strony ucznia (jakkolwiek w ostatnich latach upowszechnia się i praktyka tak zwanych kontraktów między nauczycielem a uczniem). Nauczyciele zwracają też uwagę, że - w warunkach „rynkowych" - jakiekolwiek próby zostawiania uczniów na drugi rok w klasie 
kończą się niepowodzeniem ze względu na „rynkową wartość” szkoły, szczególnie zaś na rankingi.

Mechanizmy „przemysłu rankingowego”, jak zauważa mgr Karol Jaworski, mogą również działać przeciwnie, stając w sprzeczności z zakładanymi oczekiwaniami państwa wobec szkół, by podmiotowo i w sposób zindywidualizowany podchodzić do uczniów, bowiem ta sama troska o „rynkową wartość" szkoły prowadzi też czasem do daleko idącej selekcji, a w skrajnych przypadkach - skłaniania uczniów stanowiących balast do przeniesienia się do innej szkoły. W poczuciu, że rankingi pogłębiają nierówności, w krajach skandynawskich zatem rezygnuje się $\mathrm{z}$ tego instrumentu hierarchizacji.

Ten pracujący w renomowanej szkole młody nauczyciel ma jednak zarazem poczucie - wspólne zresztą reprezentantom różnych generacji w tym gronie dyskutantów - że określenie „traktowanie podmiotowe ucznia” może stać się (i często się staje) przykrywką dla patologii relacji ucznia z nauczycielem, w której ten ostatni stawiany jest na pozycji nawet nie współrzędnej, ale podrzędnej. Tym bardziej dotyczy to relacji nauczyciel - rodzic, ponieważ rzadko przyjmuje ona postać prawdziwej współpracy, najczęściej wyradzając się w roszczenie ze strony tego drugiego. W sytuacji rynkowej niemal zawsze rodzic uzyska w kuratorium zapewnienie, że ma rację, a nie ma jej nauczyciel. W taki sposób ten ostatni zostaje postawiony wobec opresji zarówno wewnętrznej, jak i zewnętrznej.

Te doświadczenia także są niezależne od poziomu szkolnictwa. $Z$ podobną sytuacją spotykamy się na uczelniach, gdzie, jak stwierdza prof. Magdalena Saganiak (a nie występuje tu ona we własnej sprawie), źródłem patologii stają się między innymi ankiety studenckie. Ma do nich wgląd wiele osób (władze wydziału, członkowie komisji wydziałowych, członkowie komisji senackich i zewnętrznych), zatem jeśli znajdują się w nich oszczerstwa, to mogą stać się one także narzędziem szkalowania, przed którym wykładowca nie jest nawet zdolny się bronić. W niektórych przypadkach zaś ankiety studenckie stają się narzędziem mobbingu wobec niewygodnych wykładowców.

Anonimowe ankiety nie zmuszają oceniających do żadnej odpowiedzialności za słowo - a bardzo często wypowiadają się ci, którzy traktują je jako wyraz repulsji, odegrania się, a co najmniej wylania żalów, które dotyczą raczej tego, że wykładowca zbyt wiele żąda, niż zbyt mało daje. Ponieważ nie można $\mathrm{z}$ nimi dyskutować, skłaniają one wielu wykładowców do zaniżania wymagań i zawyżania stopni. Zdarza się także, że same dyrekcje instytutów, wysłuchując zażaleń studentów, skłaniają do przyjęcia takiej postawy. Oczywiście w imię respektowania wymagań mechanizmów rynkowych.

Teoretycznie, zarówno wołanie o demokratyzację stosunków nauczyciel/ wykładowca akademicki - uczeń/student, jak i stosunków nauczyciel - rodzic 
oparte jest na pięknie brzmiących hasłach wprowadzania partnerstwa, uczenia kolektywnego działania, rozwijania samorządności, przełamywania bierności społeczeństwa. Zasadnicze pytanie jednak brzmi: czego w istocie ma dotyczyć to partnerstwo i współdziałanie? Bo jeśli kwestii merytorycznych, na które w ferworze aneksji rozciąga się aktywność uczniów i rodziców zainicjowana w sferze form realizacji procesu wychowawczo-dydaktycznego, to należy się zastanowić, dlaczego takie oczekiwanie jest kierowane pod adresem nauczyciela, a nie, dajmy na to, lekarza i nie wprowadza się demokratycznej zasady leczenia, zgodnie z którą pacjent stawia sobie diagnozę, zapisuje leki, wypisuje zwolnienia - oraz kontroluje, czy lekarz właściwie wprowadza jego życzenia do komputera? Dlaczego nie stosujemy demokratycznej zasady funkcjonowania prawa, dzięki której nie prawnicy będą je formułowali i egzekwowali, ale ci którzy mu podlegają? To szczególne, że nie każdy może być bodaj elektrykiem czy drwalem, a można odnieść wrażenie, że każdy czuje się uprawniony do wskazywania nauczycielowi, co i w jaki sposób powinien wykonywać, a tym samym - do odbierania mu autorytetu i jego godności zawodowej.

Przede wszystkim zatem merytoryczny zakres oceny nauczyciela powinien być powierzony wyłącznie nauczycielowi - niezależnie od tego, czy w szkole, czy na uniwersytecie. Oznaczać to musi zerwanie ze strategią podejrzeń, prowadzącą do dezintegracji środowisk nauczycielskich. Zadawanie pytania uczniowi/studentowi (lub rodzicowi), czy nauczyciel/wykładowca akademicki jest merytorycznie przygotowany do zajęć, zakłada, że odpowiadający muszą posiadać większą od niego wiedzę pozwalającą na taką ocenę, co jest nielogiczne ex definitione. Jeśli zaś mają, niech zatem prowadzą zajęcia. Także jednak w szerszym zakresie powinny oceny pracy nauczyciela/nauczyciela akademickiego dokonywać wyłącznie merytorycznie przygotowane do tego osoby, natomiast opinie uczniów czy ankiety studenckie mogą być traktowane wyłącznie jako materiał pomocniczy i dotyczyć - ewentualnie - kwestii sposobu przekazywania wiedzy, ale nie jakości jej samej.

Uważamy też, że to uczeń/student jest tym, do kogo przede wszystkim należy wykonanie określonej pracy i rozliczenie się z niej - bez czego trud nauczyciela idzie zupełnie na marne. Podstawą programu naprawczego w bardzo szerokim sensie powinien stać się - egzekwowany - Kodeks ucznia (podobnie jak Regulamin studiów), pozwalający wskazać obowiązki w sposób jasny i precyzyjny, a środkiem do osiągnięcia tego celu musi stać się prawidłowo działający system ocen i egzaminów.

W przeciwnym przypadku milcząco zakłada się, że nauczyciel/wykładowca akademicki nie ma właściwych kompetencji, żeby wykonywać odpowiedzialnie swoją pracę. W istocie mogą tu zresztą pojawić się następujące dwie sytu- 
acje: rzeczywiście nauczyciel nie ma takich kompetencji lub nie ma kompetencji najwyższych, a dzieje się tak dlatego, że do szkoły przyjmowane są osoby niewłaściwe - na skutek selekcji negatywnej lub dlatego, że stoi za tym nepotyzm, pozwalający zebrać grupę ludzi wystarczająco podległych dyrekcji albo władzom samorządowym, by te mogły darować sobie zajmowanie się, w ich pojęciu, zbędnymi problemami. To jednak należałoby wykorzenić u samych podstaw - i wrócimy do tej kwestii dalej. Najczęściej bywa jednak raczej zupełnie przeciwnie: nauczyciel posiada odpowiednie kompetencje, wykazał się nawet doktoratem (czy stopniami akademickimi na uczelni) i nieprzeciętnym zaangażowaniem w swoją pracę, jest więc twórczy - czego się podobno od niego głównie oczekuje - a jednak z jakichś trudno zrozumiałych względów poddawany jest wielostronnej i nieustannej, a przede wszystkim nieuzasadnionej, kontroli.

Nauczyciel, i szkolny, i akademicki, odarty z autorytetu właściwego jego zawodowi, występuje w roli podejrzanego, zmuszanego do nieustannego dokumentowania wszelkich swoich działań. Obowiązujący na uczelniach, co podniósł prof. Marek Stanisz, system mierzenia jakości pracy pracowników naukowo-dydaktycznych - oczywiście system punktowy - powoduje wiele negatywnych zmian w funkcjonowaniu nauki w Polsce, skutkując między innymi, jak to on określił, „histerią dokumentacyjną”. Corocznie każdy aktywny pracownik naukowo-dydaktyczny składa kilka, a nawet kilkanaście sprawozdań ze swojej działalności, często niezmiernie rozbudowanych, by nie wspomnieć już o skandalu tak zwanych matryc i pozbawionych wartości dydaktycznych sylabusów $\mathrm{z}$ ich zaiste zadziwiającymi celami. W szkole, w skrajnych przypadkach, pod rygorem odpowiedzialności służbowej nauczyciel wpisuje do elektronicznego dziennika dane o każdym uczniu z każdej objętej przez niego nauczaniem klasy (powiedzmy, dziennie ok. 150-200 wpisów), dotyczących - często - wszystkiego. Dziennik ten, o ile ułatwia same zapisy i w dużym stopniu automatyzuje sprawozdawczość, to, jak zauważa mgr Joanna Zaremba, generuje również wymagającą poświęcania dalszego czasu korespondencję z rodzicami. Niezależnie zresztą od tego biurokracja w szkołach rośnie w sposób lawinowy. Właściwie z każdej czynności nauczyciel powinien składać sprawozdanie. Problem jednak polega w tej sytuacji na tym, że kreatywność nauczycieli/wykładowców akademickich (podlegająca, jak to określa prof. Tadeusz Sławek, pseudoregulacji przez opresję systemu biurokratycznego nieustanne wzmacniającego narzędzia nadzoru), staje się tylko pustym frazesem nieznajdującym swojego faktycznego przełożenia na premiowanie tego, co w ich pracy rzeczywiście istotne: zaangażowania, aktywności i pomysłowości. Jeśli zatem istnieje jakaś relacja między biurokratyzacją a tym, 
co stanowi sedno nauczycielskiej pracy, to wyłącznie i absolutnie negatywna. Bezpłodne mnożenie papierów zabiera mianowicie czas i siły, które powinny zostać skierowane raczej na konkretną i rzeczywistą pracę dydaktyczną.

Zarazem ta sama biurokracja służy wytwarzaniu rzeczywistości pozornej, bo papierowej (lub elektronicznej, jeśli kto woli).

Walka o wysoką pozycję w (biurokratycznie ilościowo rozliczanej) walce o klienta - na co zwraca uwagę dr Anna Ślósarz - nie pozwala na przykład egzaminatorom przy ustnym (stanowiącym składową całościowej oceny), tak zwanym „zewnętrznym” egzaminie maturalnym na bezstronność. Jeśli egzaminatorzy z dwu „zaprzyjaźnionych” szkół wymieniają się między sobą pracą w komisjach, to i wzajemnie się uzależniają: nie zdecydują się zatem na postawienie negatywnych ocen w partnerskiej szkole, wiedząc, że to samo może zostać zrobione w ich własnej na zasadzie rewanżu. W tej sytuacji połowicznym rozwiązaniem może być losowanie zewnętrznego egzaminatora (OKE dysponuje bazą), a pożądanym - wprowadzenie pojedynczego nauczyciela egzaminującego, przyjeżdżającego $\mathrm{z}$ innego powiatu/województwa (to rozwiązanie praktykowane jest np. we Francji). Póki jednak tak się nie stanie, choćby $\mathrm{z}$ tego powodu ilościowe kryteria $\mathrm{w}$ dalszym ciągu prowadzić będą do fałszowania obrazu rzeczywistości.

Jednocześnie w ciągu roku odbywa się w szkole, jak zauważa dr Dorota Utracka, kilka wewnętrznych ewaluacji, dokonywanych w zasadzie przez powołane do tego zadania grupy nauczycieli, kontrolowane jednak przez dyrekcję starającą się, by do wniosków nie przedostawały się informacje wykazujące luki, błędy czy nadużycia pokazane przez ankiety, wywiady czy dokumenty. Ogromna i czasochłonna praca nauczycieli to zabieg sztuczny także dlatego, że nie dopuszcza się narzędzi badania (np. pewnego rodzaju pytań) mogących ujawnić (kompromitujący) stan faktyczny. Za pomocą jedynie na papierze zgrabnie sporządzonej ewaluacji można zatem uruchomić mniej lub bardziej wydolną strategię maskującą istotne niedociągnięcia szkoły.

Nasze obserwacje wskazują zatem, że istniejąca dziś rozbudowana kontrola nie służy wykrywaniu patologii, lecz, choćby w sposób przedstawiony wyżej, sama jest patologiczna i staje się źródłem patologii - oderwana od faktów, nienastawiona na rzeczywistą poprawę sytuacji, kreuje autonomiczną „papierową” rzeczywistość, służąc osiąganiu nie celów edukacyjnych, lecz, podobnie jak techniki reklamowe, rynkowych lub - biurokratycznych, przydatnych, być może, do czegoś (do notującej same „wzrosty” statystyki) i komuś (politykom), ale z całą pewnością nie szkolnictwu.

Obserwacja ta nie zawęża się do szkolnictwa podstawowego i średniego szczebla. Z podobnymi problemami mamy do czynienia na uniwersytetach. 
Jak zwraca uwage prof. Magdalena Saganiak, obecna ustawa o szkolnictwie wyższym, w której sama biurokracja (łącznie z parametryzacją) wydawała się początkowo nieszkodliwym sztafażem, okazała się sprawnym instrumentem obniżania rangi nauczyciela akademickiego. Dochodzi do tego poprzez ograniczenie swobody finansowej związanej z badaniami, jak i wprowadzenie mechanizmów kontroli sprzecznych z etyką akademicką, a w znacznym stopniu podkopujących autonomię uczelni, zawężających i usztywniających ofertę programową oraz ułatwiających przekształcenie uniwersytetów w wyższe szkoły zawodowe. Ponieważ przy tym uczelnie przyjęły zaproponowane/narzucone przez ministerstwo efekty kształcenia w większości bez modyfikacji, to określone tak ogólnie, że mają pasować do wszystkich uczelni, są one zarazem tak minimalistyczne, że (na przykład) w zakresie wiedzy w obrębie kształcenia literackiego i językowego na filologii polskiej zaspokoić by je potrafił program liceum. A skoro zarówno student, jak i urzędnik ministerialny mają prawo do stwierdzania zgodności owych efektów z programem nauczania, to studenci mogą się w związku z tym domagać zmniejszania stawianych im wymagań, a urzędnicy - redukcji programów. W ten sposób dokonać się może rzeczywiste przekształcenie uniwersytetów w wyższe szkoły zawodowe nie z powodu ich obecnego poziomu kształcenia, lecz dzięki biurokracji - jako że założony wcześniej „ranking” (uniwersytetów „flagowych” i „innych”) zostanie w ten sposób ustanowiony.

Oczywistym w tej sytuacji zasadniczym zgłaszanym przez nas postulatem musi być wyeliminowanie biurokracji w szkolnictwie wszystkich szczebli w imię skierowania wysiłku nauczycieli na obszary rzeczywiście znaczące w ich pracy i związane z podnoszeniem poziomu wykształcenia, a nie - stopnia biurokratyzacji. Jest to postulat, być może, mający tym większe szanse realizacji, im bardziej zostanie dodatkowo wzmocniony przez podobne, a już dochodzące do głosu, żądania drobnych przedsiębiorców, lekarzy i przedstawicieli innych dziedzin, którzy borykają się z identycznym właściwie marnotrawstwem sił i środków kierowanych na cele biurokratyczne, a nie na, by tak rzec, konstytutywne dla nich działalności.

Jeśli natomiast - powróćmy do zasygnalizowanej już wcześniej kwestii - chcemy w istocie wykluczyć możliwość powstawania patologii po stronie nauczyciela, to musimy raczej - taki postulat wyartykułowany został przez prof. Tadeusza Budrewicza - domagać się znakomicie działających uniwersyteckich polonistyk, a w ich ramach równie dobrze funkcjonujących zakładów czy katedr metodyki i dydaktyki, których potencjał naukowy należy wzmacniać, a nie osłabiać (np. przez dokonywane w imię oszczędności łączenie metodyk/ dydaktyk w zakresie nauk humanistycznych). Jeśli chcemy natomiast wyklu- 
czyć sytuacje, w których do tego zawodu trafią osoby, za którymi stoi nie merytoryczne przygotowanie, ale znajomości i nepotyzm, należy wystąpić do MEN $\mathrm{z}$ wnioskiem o akty prawne zmieniające rolę samorządów, jeśli chodzi o merytoryczne, osobowe i finansowe funkcjonowanie szkół, a przede wszystkim wnioskować o powrót do sytuacji, w której to MEN (a jeszcze bardziej - Ministerstwo Edukacji Narodowej i Ministerstwo Nauki i Szkolnictwa Wyższego, ponieważ zakresy ich działania muszą uwzględniać ten system naczyń połączonych, w którym źle przygotowani uczniowie/studenci stają się źle przygotowującymi nauczycielami/wykładowcami, którzy kształcą źle przygotowanych abiturientów etc. - co napędza błędne koło niekompetencji na wszystkich poziomach) jest w najwyższym stopniu odpowiedzialny za stan szkolnictwa w Polsce, ponieważ to państwo polskie poświadcza swą pieczęcią świadectwo szkolne.

W tych kwestiach, adresowanych do ministerstw, na co zwraca uwagę i pomysłodawca, i prof. Teresa Kostkiewiczowa, potrzebne jest wszelako ustalenie wspólnej płaszczyzny działania i porozumienie środowisk nauczycieli - akademickich, równie jak uczących w szkołach. Wydaje się, jak zaznaczają mgr Katarzyna Porembska i mgr Daniel Zych, że zbyt łatwo godzą się one z różnymi zarządzeniami tak zwanych decydentów (ministerstw, gmin, CKE, OKE), toteż oprócz protestów czy artykułów w prasie potrzebne są i ze strony samych nauczycieli czy dyrektorów gesty bardziej wyraziste i zdecydowane - łącznie z odmową wykonywania szkodliwych dla edukacji działań i żądaniami dotyczącymi działań potrzebnych i koniecznych.

Przez cały czas, co należy podkreślić, odwoływałam się tutaj do obserwacji przedstawianych przez nauczycieli polonistów (w tym nauczycieli akademickich), dla których słowo - jak podkreśla prof. Teresa Kostkiewiczowa - jest podstawowym narzędziem poznania i porozumienia. Odnosi się ono bowiem do wszystkich innych obszarów życia i kultury (w tym posługujących się obrazem - o którym mówi się za pomocą słowa, używanego nawet przez reprezentantów postmodernizmu, i także wtedy, gdy za pomocą słowa przyznają oni obrazowi zasadnicze znaczenie) oraz do ustanawiania relacji międzyludzkich. Tymczasem coraz częściej także w szkole obserwuje się ucieczkę od słowa i nawet wykład zamieniany bywa w wystąpienie multimedialne. W konsekwencji nierzadko można też usłyszeć odpowiedź uczniów: „Ja wiem..., ale nie umiem tego ująć w słowa”. Wiedza merytoryczna, społeczna, a także, co nieobojętne, wiedza o samym sobie - i to w jakiejkolwiek dziedzinie - która nie poddaje się wysłowieniu, staje się jednak bezpłodna. Jeśli z tego nie będą zdawać sobie sprawy wszystkie strony odpowiedzialne za proces kształcenia - nauczyciele, uczniowie/studenci, rodzice, ministerstwo, a także władze łącznie z czwartą władzą, to znaczy mediami (które, naszym zdaniem, mylą się, gdy 
schodzą w walce o klienta na najniższy poziom komunikatywności i wiedzy) - być może w nieodległej przyszłości zapadnie martwa cisza lub z ust większości w następnych pokoleniach wydobędzie się jedynie nieartykułowany bełkot.

Podejmująca ten wątek dr Dorota Utracka stwierdza, że nakłada to na proces edukacji polonistycznej i na nauczycieli polonistów szczególne zobowiązania. Wydaje się, że szkoła i uczelnia, a w ich ramach edukacja polonistyczna, to ostatnie dziś miejsca, gdzie możliwe jeszcze jest promowanie i egzekwowanie wzorców kultury mówienia - spójnego, poprawnego leksykalnie, zorganizowanego semantycznie i formalnie - kształtujące kodeks poprawnej komunikacji. Wypracowywanie jednak właściwych nawyków komunikacyjnych, dyscypliny, estetyki i etyki mówienia wymaga cierpliwości i powolnej, żmudnej „pracy w słowie”. Bez włożenia tego trudu wszelako młody (i dorosły) człowiek będzie obawiał się (bo nie będzie umiał) mówić i pisać w urzędach, instytucjach publicznych, a okaże się też niekomunikatywny w kontaktach osobistych, nie potrafiąc wyartykułować nie tylko swoich racji, ale i zwyczajnie wyjaśnić, o co mu tak naprawdę chodzi. Jakość komunikacji słownej lokuje ponadto i określa człowieka społecznie i kulturowo, często decydując o statusie społecznym a nawet, tak eksponowanym dziś, tworzeniu wizerunku, ale także (w tym w „branżach” niehumanistycznych, jak ekonomia, zarządzanie, marketing) pozwala budować relacje interpersonalne, organizować zespół, rozwiązywać konflikty drogą negocjacji i mediacji. Wbrew pozorom nawet w zmedializowanym i skomercjalizowanym świecie słowo ciągle pozostaje podstawowym wyznacznikiem relacji międzyludzkich. W zakresie treści, ale i metod, na wszystkich poziomach kształcenia powinna więc zostać znacząco wyeksponowana szeroko rozumiana kompetencja językowa, pozwalająca eliminować skrótowość i ogólnikowość („hasłowość”) porozumienia oraz przemoc językową (tzw. mowę nienawiści), przynosząca zaś w zamian bogactwo i funkcjonalność języka budowane dzięki wiedzy literacko-kulturowej, a w jej obszarze - dzięki łączeniu tego, co lokalne, osobiście doświadczane, z tym, co globalne i wielokulturowe, oraz tego, co powiązane z tożsamością równie jak z innością.

Odpowiedzialnością za potencjalne zagrożenie wspomnianą wyżej ciszą lub nieartykułowanym bełkotem nie można jednak obarczać nauczycieli występujących w roli kozłów ofiarnych, choć być może niektórzy z nich nie powinni się znaleźć w tym zawodzie, a kwestia doboru do niego pozostaje jedną z podstawowych - i choć postulat, by wypracować na uczelniach oraz w dyrekcjach szkół mechanizmy pozwalające na precyzyjną selekcję do zawodu już wybrzmiał na poprzednim Kongresie, to jednak warto go przypomnieć w związku, chociażby, z brakiem odpowiedzi nań ze strony dyrektorów czy 
władz szkolnych. Jednak większość nauczycieli, szczególnie polonistów, podkreślmy to raz jeszcze, nie tyle nie potrafi, ile nie jest w stanie skoncentrować się przede wszystkim na zasadniczych merytorycznych i wychowawczych zadaniach, ginąc nie tylko pod nawałem prac do sprawdzania, ale i pod zalewem biurokratycznych obciążeń (procedury ewaluacyjne, sprawozdania, rozkłady zajęć), nie służących w żadnej mierze temu, co ma stanowić właściwy cel szkoły.

To domaganie się przywrócenia właściwego miejsca zadaniom stanowiącym o tożsamości szkoły podnoszone jest $\mathrm{z}$ mocą przez naprawdę dobrych, aktywnych i mądrych nauczycieli, biorących udział w naszej dyskusji - nieszukających bynajmniej ucieczki przed pracą, szukających jednakże ratunku przed pracą absolutnie bezpłodną. Podobne żądanie płynie ze środowiska akademickiego. Jeśli prawdą jest, że takie będzie społeczeństwo, jakie ,jego młodzieży chowanie”, to musimy się zastanowić, czy podjąć to zadanie może nauczyciel, któremu odbiera się jego status i którego się lekceważy?

Uważamy, że konieczne staje się podjęcie starań służących przywróceniu godności i autorytetu - wymagającego, dobrze przygotowanego do swej pracy i twórczego - nauczyciela, szczególnie nauczyciela polonisty i humanisty, choć nie wyłącznie. Trzeba też podjąć działania zmierzające do odwrócenia tendencji deprecjacji polonistyki i humanistyki w ogóle - przede wszystkim tej dokonywanej poprzez środki masowego przekazu - jako szczególnie, a bezmyślnie, niszczącej. Pośród niewykorzystanych instrumentów to właśnie umożliwiających powinna znaleźć się, o czym przypomina prof. Magdalena Saganiak, Ustawa o języku polskim zobowiązująca do poprawności językowej w przestrzeni publicznej (w prasie, radiu, telewizji, dokumentach urzędowych). Rodzi się tu więc oczywisty postulat, by szczególnie w tej sferze nie pojawiały się teksty pisane i wypowiedzi niepoprawne czy nieporadne językowo. Przede wszystkim też w tych obszarach powinno się zatrudniać specjalistów chroniących język. Nie polonistów-policjantów zresztą, a właśnie - w szerokim sensie tego słowa - nauczycieli. W tej mierze nieodzowne jest szerokie i, dodajmy, naprawdę konkretne działanie. Przykłady kilku państw mogą służyć nam pomocą $\mathrm{w}$ rozwiązywaniu tego problemu.

Jeśli jednak przypisujemy humanistyce zasadniczą rolę w uczeniu człowieka porozumiewania się, wypowiadania, myślenia, odczuwania, to protestując przeciw dewaluacji roli nauczyciela polonisty i humanisty we wszystkich środowiskach, szczególnie powinniśmy - jak podkreśla mgr Anna Nakielska-Kowalska - zwrócić również uwagę na swoje własne środowiska, na przykład promując klasy humanistyczne i występując przeciw twierdzeniom, że uczniowie o humanistycznych inklinacjach to słabi, „wybrakowani” uczniowie, a nie uczniowie o po prostu innych predyspozycjach niż „ścisłowcy”. Mgr Mi- 
rosław Skrzypczyk akcentuje przy tym, że potrzebna jest dziś polonistyka bardziej ofensywna i „performatywna”, kreująca swój obraz jako dziedziny poważnej - a możliwe to stanie się tylko wtedy, gdy środowisko polonistów (humanistów) będzie także zabiegać o stanie się wspólnotą, która w poczuciu solidarności wspiera się wzajemnie, choć również - w imię tej samej solidarności - od siebie wiele wymaga. Humaniści i poloniści są dużą grupą, ale dzisiaj kompletnie zatomizowaną, rozproszoną, bez silnego i wyrazistego głosu, a ich wystąpienia często naznaczone są brakiem zrozumienia dla siebie samych i wzajemnymi pretensjami (np. oskarżeniami o niedociągnięcia powstające na jednym poziomie, a konieczne do odrabiania na innym), gdy tymczasem przyczyny tego stanu rzeczy są w znacznej mierze raczej obiektywne niż subiektywne, i związane na przykład z brakiem wystarczającego czasu czy za dużą liczbą uczniów w klasie/grupie studenckiej.

Warto więc, aby nauczyciele wszystkich poziomów edukacji szkolnej i pracownicy uniwersytetów komunikowali się ze sobą (pada tutaj propozycja, by nauczyciel języka polskiego utrzymywał kontakt z promotorem czy mentorem na uczelni, który wspierałby go w jego działaniach edukacyjnych i towarzyszył jego poszukiwaniom oraz rozwojowi), słuchali siebie (dobrzy nauczyciele uczący w szkołach średnich, a nawet emerytowani nauczyciele, mogliby służyć swoją wiedzą, umiejętnościami, a przede wszystkim doświadczeniem studentom - przyszłym nauczycielom - w ramach warsztatów i ćwiczeń, powiedzmy, podczas zajęć z metodyki - podpowiadają mgr Katarzyna Porembska i mgr Daniel Zych) i spotykali się ze sobą (Kongres czy skromne Fora TLiAM stwarzają również taką możliwość), by wspólnie wypracować n a s z e własne stanowisko i zbudować o sobie wyraźną i przekonującą narrację zdolną przeciwstawić się często trywialnym, nieodpowiedzialnym i populistycznym opiniom, które podważają sens pracy nauczyciela. Nie jest to może łatwe, bo wymaga dodatkowego czasu i wysiłku, ale wydaje się nieodzowne.

\section{EGZAMINY SZKOLNE JAKO NARZĘDZIE KSZTAŁTUJĄCE SPOSÓB I EFEKTY KSZTAECENIA}

\section{A. Diagnoza stanu istniejącego}

Przypomnijmy: słowo egzamin wywodzi się z łaciny, w której oznacza 'dokładne ważenie’, a jest sprawdzaniem przez osoby kompetentne czyichś wiadomości naukowych lub fachowych po jakimś etapem kształcenia lub przed nim, pełni więc rolę pewnej granicy pozwalającej przejść na wyższy etap czy poziom komplikacji zadań, związany tyleż z większą wolnością, ile odpowiedzialnością - a więc i d oj r z a ło śc i ą. W jakim więc stopniu 
dzisiejsze egzaminy są takim w a ż e n i e m (przy całej metaforyczności tego określenia - w ujęciach rynkowych trywialnie pozbawianego przenośnego sensu jakościowego wymiaru owego ważenia) i w jakim stopniu oceniają one pr z y r o s t wiedzy, umiejętności, kompetencji ucznia, szczególnie p o pewnych etapach?

Otóż nauczyciele (podkreślę jeszcze raz: znakomici nauczyciele) biorący udział w obradach MFE TLiAM są zgodni. Mimo że tegoroczny egzamin maturalny w większości wypadków (choć nie bez wyjątków) został przyjęty nieco lepiej niż poprzedni (brak kluczy w pisemnej części), to jednak wystąpiły w nim poważne luki i błędy. Podstawowe zaś problemy stwarzają sposób formułowania wymagań, budzący poważne wątpliwości co do poziomu oczekiwań egzaminacyjnych, i kryteria oceniania, pozwalające egzaminatorom na dość swobodne ich traktowanie, co podważa obiektywność oceny samej odpowiedzi.

\section{a) Matura pisemna}

Zwróćmy przede wszystkim uwagę, że - nie wspominając o nieporównywalności egzaminów w kolejnych latach - nawet w jednym roku stopień trudności dwu tematów jest zróżnicowany, co samo w sobie stanowi istotny problem, jeśli chodzi o poprawność „ważenia” wiedzy. Jednocześnie zwróćmy uwagę, że dzięki załącznikom tekstowym, które zdający ma interpretować, może on bez specjalnego przygotowania podejść do egzaminu, bowiem właściwie nie egzekwuje się od niego uprzedniej wiedzy literackiej i kulturowej. Na egzaminie pisemnym, na co zwraca uwagę mgr Joanna Zaremba, choć obniża się punktację za błędy merytoryczne, to w sposób absolutnie niezrozumiały przyznaje się zarazem punkty za... brak błędów. W interpretacji podanego wiersza trudno zrobić błąd rzeczowy, więc już na wstępie, w zasadzie za nic, piszący otrzymuje 4 punkty. Podobnie jest przy okazji oceny dotyczącej spełnienia kryterium „styl” (zasada decorum). A razem to już 8 punktów czyli całkiem spora część, bo $20 \%$ całej wartości wypracowania. Za zredagowanie tezy odpowiadającej na pytanie: „czy?” - chociaż więcej żądałoby od zdającego polecenie wymagające rozwiązania problemu, gdyż uczeń sam musiałby przemyśleć postawione zagadnienie - abiturient automatycznie otrzymuje 6 punktów (ponad 10\% punktacji za całe wypracowanie). Razem to już jedna trzecia nader wyrozumiałego „ważenia”.

Skąd te akty nieuzasadnionej hojności? Można odnieść wrażenie, że kryteria po zmianach obowiązujących w bieżącym roku są w dalszym ciągu tak konstruowane, iż po prostu bardzo trudno tego egzaminu nie zdać. A jeśli ktoś się bardzo o to ostatnie już postara, nie zmienia to pytania o poziom wykształ- 
cenia polonistycznego tych, którzy zdali, ponieważ, co nauczyciele podkreślają wyraźnie i zgodnie, nawet średnio inteligentny uczeń może nie mieć prawie żadnej wiedzy ani umiejętności, aby zdać. Wystarczy, że posługuje się z grubsza poprawnym językiem i w miarę logicznie rozumuje ${ }^{2}$. Tym samym cel, dla którego stosuje się egzaminy, zostaje podważony, a sam egzamin staje się listkiem figowym przykrywającym wstydliwy fakt braku u zdających wiedzy.

Ogólne zapisy poziomów realizacji wypowiedzi pisemnej utrudniają też niuansowanie różnic ${ }^{3} \mathrm{w}$ poszczególnych pracach, szczególnie w zakresie wykorzystanych tekstów kultury (podobnie zresztą ocena poprawności językowej jest zbyt płaska - to jedynie trzy poziomy: 6, 3 i o punktów). Jeśli uczeń zaledwie pobieżnie odniósł się do wymaganej liczby tekstów kultury, na przykład z zakresu gimnazjum lub lektur typu Harry Potter, to uzyskuje o 4 punkty (czyli niemal 10\%) więcej niż ten, który szczegółowo opracował mniej tekstów, za to bardziej ambitnych. Proponowane kryteria ilościowe, nie promując zatem pogłębionych, ciekawych i mądrych prac nastawionych na jakość inte-

2 Przeprowadzona przez mgr Joannę Zarembę symulacja pokazuje rzecz jasno. Uczeń realizuje temat: „Czym może być dla człowieka podróżowanie? Rozważ problem i uzasadnij swoje stanowisko, odwołując się do podanego fragmentu reportażu Ryszarda Kapuścińskiego oraz innych, wybranych przez siebie, tekstów kultury. Twoja praca powinna liczyć co najmniej 250 słów" (przykład zaczerpnięty z dokumentu Egzamin maturalny od roku szkolnego 2014/2015. Język polski. Poziom podstawowy. Rozwiązania zadań i schematy punktowania, 2013). Stawia tezę: podróż jest przygodą i poznaniem świata; A = 6 pkt. Odwołał się w miarę sensownie do załączonego tekstu, do Kubusia Puchatka i Małego Księcia (bez jakichkolwiek antropologicznych kontekstów); B = 12 pkt. Pracę napisał bez błędów rzeczowych; $\mathrm{C}=4$ pkt. Kompozycja budzi pewne zastrzeżenia; $D=3$ pkt. Spójność logiczna - też; $E=2$ pkt. Styl - poprawny; F = 4 pkt. Język z błędami; G = 3 pkt. Niech i ortografia, dla poprawienia humoru zrozpaczonego poziomem przywołanych lektur nauczyciela, nie będzie idealna; $\mathrm{H}=2$ pkt. Razem: 36 punktów, czyli 72\% całkowitej wartości wypracowania. Jeśli ten uczeń dobrze napisał test i pisze lepszym językiem niż założyliśmy - może uzyskać ponad 80\% punktów i studiować polonistykę (w tym roku 84\% to wartość centyla: 91!).

3 Obniżanie poprzeczki egzaminacyjnej i brak niuansowania, zawarte już w samych zaleceniach do egzaminu pisemnego - dodatkowo wzmocnione przez zdających odruchem ratowania się z odmętów zbyt szerokiej dla wielu rzeki - w przypadku egzaminu ustnego stanowi, jak się zdaje, wyjaśnienie zaobserwowanego przez jednego z dyskutantów pozornego zrównania wiedzy i umiejętności wcale nie tak samo przygotowanych (znakomitych, bardzo dobrych, dobrych, średnich i słabych) uczniów, jakie ujawniło się w wynikach z egzaminu maturalnego: wszyscy napisali go bowiem na poziomie podstawowym podobnie i zmieścili się w przedziale 10\% (to znaczy między $70 \%$ a 80\%). To nie tylko dziwne i zaskakujące, ale i demoralizujące. Taka sytuacja nie sprzyja traktowaniu języka polskiego jako poważnego przedmiotu, a egzaminu jako ważnego i wiarygodnego sposobu weryfikującego wiedzę i umiejętności - jak podkreślił mgr Mirosław Skrzypczyk. 
lektualną, są dodatkowo antywychowawcze i stają się przyczyną demoralizacji uczniów, ponieważ ci, wiedząc, jak się je stosuje, nie czują się ani zachęceni, ani zobowiązani do pracy i nauki. Na egzaminacyjną „wagę” wszakże można położyć sporo, ale w zasadzie mało istotnych jakościowo, elementów, a ta wskaże ich wystarczalność. „Waga” jest zatem zdefektowana i wszyscy o tym wiedzą.

W konsekwencji - pomijając już inne kwestie - prowadzi to do destrukcyjnego dla najlepszych „równania w dół” zamiast w górę, naprawdę w sposób szokujący czasami odczuwalnego następnie (zwraca na to uwagę prof. Tadeusz Sławek) na wyższych poziomach kształcenia.

\section{b) Matura ustna}

Zacząć trzeba od takich podstawowych mankamentów matury ustnej, jak możliwy brak obiektywizmu („wyrozumiałości”) egzaminatorów z „partnerskich” szkół z uwagi na rankingi (niestety), na możliwość szybkiego udostępniania przez zdających wylosowanych przez nich pytań w mediach społecznościowych i niewłaściwe formułowanie poleceń przez CKE. W 2015 roku (zwraca na to uwagę mgr Marek Urbanowicz) pojawiły się ponadto na maturze ustnej zadania świadczące o braku znajomości przez układających je programu nauczania; na przykład polecenie, by zdający na podstawie podanego „wybranego tekstu kultury oraz własnych doświadczeń językowych” wyjaśnił, „czemu służą innowacje frazeologiczne w języku”. W liceum nie uczy się o funkcjach innowacji frazeologicznych, a trudno jest wymagać od abiturienta, by pamiętał innowacje frazeologiczne w omawianych kiedyś tekstach literackich.

Jednak ustny egzamin maturalny budzi przede wszystkim wątpliwości związane z ogromnym zróżnicowaniem poziomu trudności (zwraca na to uwagę mgr Joanna Zaremba) poszczególnych typów pytań. O ile przy zadaniach z tekstem literackim można było odwołać się do tekstów kultury (np. filmów), to trudniejsze okazały się zadania z tekstem ikonograficznym (i koniecznym odwołaniem się do tekstów literackich), a najwięcej kłopotów sprawiały zadania związane z zagadnieniami językowymi, wymagające przytoczenia przykładów ilustrujących tę problematykę w różnorodnych tekstach kultury oraz przedstawienia własnych doświadczeń językowych. Jak zatem porównać wyniki ucznia, który mówił o źródłach szczęścia na podstawie fraszki $\mathrm{Na}$ dom $w$ Czarnolesie Jana Kochanowskiego (łatwo otrzymać 100\% punktów) oraz tego, który miał do czynienia z problemem językowego zaintrygowania czytelnika w tekście Ewy Wolańskiej Współdziałanie słowa i obrazu w prasie tabloidowej i szukał gorączkowo w pamięci odpowiednich przykładów i cytatów (trudno uzyskać choćby 50\%). Na zaświadczeniu z wynikami egzaminu ustnego nie wskazuje się stopnia trudności pytania. Tak więc od uczniów część 
zagadnień wymagała posiadania wiedzy na bardzo wysokim poziomie erudycji i kompetencji, które trudno wykształcić na lekcjach języka polskiego w zakresie podstawowym, choćby z powodu braku czasu, a część - na doprawdy niewielkim.

W konsekwencji jednak pojawiało się w tej sytuacji rozwiązanie problemu paradoksalne (zwraca na to uwagę mgr Mirosław Skrzypczyk): egzamin ten nie aktywizował pogłębionej wiedzy, ani nie wynikał z doświadczenia szkolnego i nauczania języka polskiego, lecz otwierał pole do swobodnych interpretacji, a nawet dywagacji, odległych skojarzeń i powierzchownych sądów, a tematy, wykorzystujące różne teksty kultury, sprzyjały ugruntowaniu się przekonania, że humanistyka opiera się na ogólnikach, wolnych skojarzeniach, swoistym „laniu wody” i na tym, „co mi przychodzi do głowy”. Zarzut braku profesjonalizmu w czytaniu tekstów kultury (dziedziny złożonej i skomplikowanej) można przy tym postawić w takim przypadku zarówno uczniom, jak i nauczycielom egzaminatorom - bo przecież warto przypomnieć, że przedmiot ,język polski” opiera się przede wszystkim na zajmowaniu się językiem i literaturą, natomiast czytanie innych tekstów kultury stanowi jego dopełnienie, a nie istotę.

\section{c) Poziom rozszerzony}

Swoje zastrzeżenia na temat zadań z poziomu rozszerzonego $\mathrm{w}$ arkuszu maturalnym z roku 2015 zgłosiła mgr Joanna Zaremba. W przypadku zadania pierwszego, wymagającego ustosunkowania się do tekstu naukowego, zły dobór materiału (fragment Historii piękna Umberta Eco o poetyce symbolizmu i roli poety w docieraniu do porządku symbolicznego świata i ujawnianiu go ${ }^{4}$ ) spowodować może ogromne trudności w ocenianiu realizacji kryterium A: „Określenie problemu uważa się za częściowo zgodne z tekstem, jeśli zdający nie w pełni rozpoznaje problem główny lub wydobywa $\mathrm{z}$ tekstu tylko problem drugorzędny". Pada pytanie, kto ma ustalić określenie głównego problemu? Konkretny egzaminator czy ekspert CKE? Czy też trzeba tak samo punktować każdą propozycję określenia problemu? Jak wtedy różnicować rozwiązania uczniowskie? Ustalenie, co jest głównym problemem w tekście Umberta Eco nie było dla zdających łatwe. Drugi temat to wariant zadania z poprzedniej formuły egzaminu realizowanej w latach 2005-2014 - analiza i interpretacja porównawcza (Zygmunta Krasińskiego Na Sybir! i Jacka Kaczmarskiego Zesłania studentów), ale bez wskazówki interpretacyjnej i w zakresie jednego ro-

4 Zob. Egzamin maturalny z języka polskiego. Poziom rozszerzony (7 maja 2015) [online], Centralna Komisja Egzaminacyjna, [dostęp: 2015-11-26]: <http://www.cke.edu. $\mathrm{pl} /$ index.php/2015-em>. 
dzaju literackiego. Zmiana ta wydaje się kosmetyczna, ale w istocie okazuje się dość istotna, szczególnie z powodu zamknięcia zestawienia w jednym rodzaju literackim, co ogranicza zakres porównania.

\section{B. Proponowane działania naprawcze}

\section{a) Uwagi dotyczące obu części egzaminu}

W tej sytuacji pada tu propozycja (artykułuje ją mgr Joanna Zaremba) zastanowienia się nad przyjęciem jakichś wspólnych zasad i kryteriów oceny wypracowań, idąc za przykładem innych systemów edukacyjnych (np. anglosaskiego). Pomimo niechęci do testów jako sposobu sprawdzania bezmyślnej pamięci, można wyobrazić sobie jednak mądry test weryfikujący wiedzę, jej wykorzystanie i uruchamianie umysłu w procesie badawczym. Do tego jednak potrzebny jest szczegółowy sylabus, bo na przykład w obowiązujących podręcznikach zakres wspólnych informacji jest niewielki, a nawet w ramach jednego wydawnictwa podręczniki różnią się zestawem informacji i/lub sposobem ich ujęcia (przykład: definiowanie narracji personalnej). Istnieje jednak tyle sposobów sprawdzania wiedzy i umiejętności, że środowisko polonistyczne mogłoby wypracować konsensus, gdyby zaistniała konieczność stworzenia testu z wiedzy ogólnej.

Ponadto: na innych przedmiotach nikt chyba nie forsuje przekonania, że umiejętności i kompetencje da sięoddzielić od wied zy, tymczasem takie przekonanie zostaje $\mathrm{w}$ gruncie rzeczy wpisane w założenia egzaminu maturalnego z języka polskiego. Należy to wyeliminować.

Niedopuszczalne jest (co z całą mocą podkreśla mgr Marek Urbanowicz) tolerowanie na egzaminach konsekwentnie popełnianych, kardynalnych błędów typu: Juliusz Słowacki napisał Dziady, Henryk Sienkiewicz jest autorem Pana Tadeusza. Błędem jest też dawanie uczniom do interpretacji na obu poziomach matury tekstów autorów zupełnie nieznanych, a na pewno niezaliczanych do klasyki, takich jak: Agnieszka Osiecka, Elizabeth Bishop, Jacek Kaczmarski. Nie mając nic wspólnego z tak zwanymi lekturami „z gwiazdką” (obowiązkowymi), nie motywują do pracy nad tymi ostatnimi. Uczniowie natomiast całkiem słusznie uważają, że w tej sytuacji przygotowanie się do tak rozumianej matury jest właściwie niemożliwe.

Prof. Marek Stanisz uważa więc, że nacisk położyć trzeba na konkretne wiadomości sprawdzane podczas egzaminów z języka polskiego (historycznoliterackie, językoznawcze, genologiczne, stylistyczne etc.), przy jednoczesnym zweryfikowaniu przekonania o rzekomo encyklopedycznym charakterze wiedzy przekazywanej na lekcjach języka polskiego, a tym bardziej o jej mętności i niedookreśleniu. Zwraca on uwagę, że wśród uczniów (maturzystów) pa- 
nuje dość powszechna opinia, że do osiągnięcia pozytywnego rezultatu z egzaminu maturalnego wystarczy głównie inteligencja i „ogólna orientacja”, a wiedza jest sprawą wtórną i mniej istotną. Nie łudźmy się: rozpowszechnione przekonanie, iż każdy na egzaminie z języka polskiego „powinien dać sobie radę", jeśli tylko wykaże się wystarczającą dozą, niekoniecznie uzasadnionej, pewności siebie, jest jedną z przyczyn obniżającego się prestiżu tego przedmiotu. I - uwaga! - nawet w Ministerstwie można usłyszeć argumentację taką, że skoro prawie wszyscy zdają maturę z języka polskiego, przedmiot ten nie wymaga żadnej dodatkowej uwagi - jakiej wymagają na przykład matematyka czy język angielski.

Tymczasem, jeżeli zdawalność matury z tego przedmiotu jest bliska 100\%, przeczy to raczej krzywej Gaussa i oznacza, że egzamin ten jest jedynie czczą formalnością, której uczeń nigdy nie będzie traktował poważnie. I nie będzie też traktował poważnie w ogóle przedmiotu, na którym w zasadzie - jak z tego egzaminu wynika - niczego się nie uczy. Chyba że wybiera się na studia zagraniczne - o czym za chwilę.

\section{b) Uwagi związane z egzaminem pisemnym}

Test czytania na poziomie podstawowym (wskazuje na to mgr Anna Nakielska-Kowalska) powinien być wzbogacony o znacznie większą liczbę pytań dotyczących omówionego w szkole ścisłego kanonu. W ocenie pracy na poziomie rozszerzonym więcej punktów przyznawać natomiast należy za konteksty interpretacyjne, mniej punktów za styl (lub na tym poziomie kryterium „styl” włączyć do kryterium „język”).

\section{c) Uwagi związane z egzaminem ustnym}

Pytania oraz kryteria oceny powinny być (to także uwagi wyżej wymienionej dyskutantki) tak zbudowane, aby sprawdzały umiejętność interpretacji tekstu lub (w tematach z nauki o języku) wyszukiwania informacji w tekście, a także znajomość tekstów literackich należących do ścisłego kanonu czy też umiejętność korzystania z kontekstów historycznych, historycznoliterackich (a więc by sprawdzały wiedzę ucznia).

W celu wyeliminowania przypadku związanego $\mathrm{z}$ wylosowaniem pytania o mniejszym lub większym stopniu trudności proponujemy wprowadzenie trzech, a przynajmniej dwu pytań (jednego z literatury, a drugiego z nauki o języku). Poza tym należy rozwiązać problem tajności zadań, na przykład podając we wrześniu zestaw około trzystu pytań sporządzonych przez CKE, z których niektóre pojawiłyby się na maturach ustnych w danym roku - z założeniem, że towarzyszące im fragmenty tekstów/tekstów kultury będą zmieniane. 


\section{d) Propozycja TLiAM w sprawie egzaminu maturalnego zgłoszona do przemyślenia przez mgra Marka Urbanowicza}

Obecny kształt egzaminów szkolnych, a szczególnie maturalnych, uznajemy za jedną z przyczyn kryzysu polonistyki. Główne zarzuty kierowane pod ich adresem to: brak mobilizacji młodych ludzi do pracy (przy okazji zaś wypieranie etosu pracy przez etos zabawy, co stanowi, naszym zdaniem, dość szczególne przygotowanie młodego człowieka do roli przyszłego pracownika) i stawianie zdającym zbyt niskiego progu wymagań - lub żadnego (w egzaminach gimnazjalnych w ogóle nie ma problemu zdawalności, gdyż samo podejście do egzaminów staje się wystarczającym warunkiem zaliczenia, podobnie jak w egzaminach kończących szkołę podstawową) - co dewaluuje zasadę kontroli konkretnych wyników, a tym samym oznacza stawianie na dowolność i przypadkowość przez uczniów.

Najważniejsze zmiany powinny dotyczyć matury pisemnej, gdyż mogą one w zasadniczy sposób podnieść poziom wiedzy, umiejętności i ogólnie poziom intelektualny abiturientów szkół średnich. Ich celem miałaby być mobilizacja uczniów do pracy, ponieważ obecnie język polski młodzież zdaje właściwie „z marszu”, czyli w żaden sposób nie podnosząc poziomu swojej wiedzy czy umiejętności. Proponowane zmiany sprawiłyby też, że wyniki egzaminów byłyby bardziej porównywalne i sprawiedliwe. Aby nie dokonywać zbyt radykalnej (kolejnej) rewolucji w obecnych maturach, wystarczyłoby uzupełnić zarówno egzamin na poziomie podstawowym, jak i rozszerzonym o testy podobne na przykład do tych, które opracowano na potrzeby egzaminów wstępnych na Uniwersytecie Warszawskim w latach 2000/2001 czy 2002/2003. Oto przykłady zadań z tych testów:

\section{Przeczytaj podaną niżej ze Słownika terminów literackich definicję:}

„[...] przeróbka utworu literackiego rozwijająca, często także swobodnie i żartobliwie upraszczająca jego treści, oddająca je za pomocą środków odmiennych niż zastosowane w pierwowzorze, przy zachowaniu jednak rozpoznawalnego podobieństwa do owego pierwowzoru. [...]".

Przytoczona definicja określa:

1.) powtórzenie, refren;

2.) parafrazę;

3.) parodię;

4.) figurę stylistyczną podobną do metafory.

Przeczytaj podane niżej hasła:

„sztuka dla sztuki”; „,nirwana”; „dekadentyzm”; „poeta wyklęty”.

Z jaką epoką są one związane? 

1.) romantyzm;
2.) pozytywizm;
c.) Młoda Polska;
d.) oświecenie.

Z którym rzeczownikiem można połączyć czasownik „formułować” , aby powstały w ten sposób zwrot był poprawny?
1.) batalion;
2.) pochód;
3.) zarzuty;
4.) charakter.

Dla którego z autorów charakterystyczne są przywołane słownictwo i stylistyka?

a.) on nadal czytał belfrem; jadł przeciwko dzieciakom; Pimko Norwidem gorszył się do pensjonarki; bezwzględny belfer tak mnie nagle zbelferzył, Matka śmiała się w Epoce;

b.) bardzo dobra szlachta, ale zaraczona; kurdypiełki zafądziane; chram na wszystko; skurczyflak; psia jego flądra; sturba twoja suka;

c.) wojna jest pokojem; wolność jest niewolnictwem; niewiedza jest siłą; dobrotryb; sekszbrodnia; obfitomin źle cytowane czekolada sprostować; proletka; bitwa wytwórczości przemysłowej została wygrana!

a) W. Gombrowicz, b) J. Tuwim, c) S. Mrożek;

a) S.I. Witkiewicz, b) J. Tuwim, c) S. Mrożek;

a) S. Mrożek, b) W. Gombrowicz, c) J. Orwell;

a) W. Gombrowicz, b) S.I. Witkiewicz, c) J. Orwell.

Formułowane według tego wzorca pytania mogłyby sprawdzać umiejętność interpretowania i analizy fragmentów utworów pisanych prozą czy wierszy, znajomość terminów literackich, ortografii i interpunkcji, zasób słownictwa, umiejętności w zakresie stylu, składni, zasad poprawności językowej.

Obecny egzamin pisemny z języka polskiego na poziomie podstawowym składa się z dwóch części: pierwszej, zawierającej polecenia do tekstu, które sprawdzają jego rozumienie, i drugiej, na którą składają się dwa zadania do wyboru - pisanie rozprawki na temat nawiązujący do podanego fragmentu lektury i wymagający odwołania się do innych tekstów kultury lub interpretację wiersza. Testy (od kilku do dziesięciu pytań) należałoby wprowadzić w części pierwszej zamiast jednego z dwóch zadań dotyczących czytania ze zrozumieniem. Trudniejsze testy (w podobnej liczbie) należałoby dołączyć do matury na poziomie rozszerzonym (co prawda, trzeba by wtedy wydłużyć czas egzaminu, co chyba nie stanowi jednak problemu, zważywszy że starą maturę z języka polskiego - przed rokiem 2005 - pisało się przez pięć godzin). 
Celem proponowanych zmian $\mathrm{w}$ formie egzaminu maturalnego $\mathrm{z}$ języka polskiego jest zerwanie z powodującym spustoszenia podejściem zakładającym, że egzamin ten powinien badać przede wszystkim poziom opanowania umiejętności. Zaniedbywanie wymagań dotyczących przynajmniej podstawowego poziomu wiedzy prowadzi do ubóstwa intelektualnego przejawiającego się w ograniczonym słownictwie i zasobach myślowych, a tym samym prowadzi do zawężenia możliwości uczestniczenia w świecie kultury i w ogóle w życiu społeczeństwa - ponieważ z pustego i Salomon nie naleje.

\section{Uwagi o podstawowym charakterze}

Po pierwsze - i stwierdzamy to zgodnie - zdumiewającym paradoksem pozostaje, że wyniki egzaminu maturalnego z języka polskiego interesują uczelnie zagraniczne i brane są pod uwagę, a nawet mogą mieć decydujące znaczenie, przy rekrutacji na studia poza Polską, a nie mają znaczenia w kraju. Wydaje się, że najbardziej oczywistą kwestią - i receptą na zwiększenie wagi przywiązywanej do egzaminu maturalnego z języka ojczystego (pisemnego i ustnego) przez uczniów - jest uznanie jego rangi przez rodzime uczelnie wyższe i potraktowanie go jako ważnego elementu rekrutacji na wszystkie kierunki studiów. Z takim postulatem należy zwrócić się do rektorów szkół wyższych. Ale, być może, należy też przedtem przeprowadzić akcję informacyjną w tej kwestii, zwracając się o pomoc do ośrodków opiniodawczych i mediów.

Po drugie, na podsumowanie dotychczasowych konstatacji dodam, że budzi szczególne zastanowienie to, do jakiego stopnia zazębiają się ze sobą dwie przeciwstawne tendencje. $Z$ jednej strony mianowicie obserwujemy dochodzącą do granic absurdu k o n $\mathrm{t}$ r o l ę sprawowaną przez biurokrację (ale co właściwie oznacza ta anonimowość, w czyim interesie działa ta bliżej nieokreślona grupa, a nawet władza?), dotykającą zaś nauczycieli (wszystkich stopni), to jest ludzi dojrzałych, w zasadzie autonomicznych i wykształconych, a nawet posiadających najwyższe kompetencje (w przypadku profesorów wyższych uczelni). Z drugiej natomiast strony obserwujemy sprowadzany do granic absurdu b rak w y magá i k o n t rol i wobec ludzi młodych, dopiero podlegających kształtowaniu - niezależnie od tego, czy formować się ma ich indywidualność czy zdolność do życia społecznego. Zwłaszcza ten rodzaj kontroli, jaki obserwujemy w przypadku egzaminów dojrzałości, każe mówić o ich fasadowości, za którą idzie demoralizacja obu stron: obojętniejących nauczycieli, którym podopieczni mówią wprost: „My i tak to zdamy”, i lawirujących uczniów, którzy nie wykonują swego podstawowego zadania, to znaczy nie uczą się tego, co ma charakter merytoryczny i zapewnia im przynajmniej podstawową wewnątrzsterowność. Zauważmy jednak, iż fakt, że nie podlegają oni 
kształtowaniu przez szkołę, nie oznacza przecież, że nie podlegają kształtowaniu na przykład przez rynek - rynek rozrywki, rynek mediów elektronicznych, rynek towarów, w tym narkotyków oraz przez b r a k - zapewniającego im bezpieczeństwo socjalne - rynku pracy. Czy w tej sytuacji szkoła powinna mówić „pas” i oddawać pole jedynie tym instytucjom, które dbają wyłącznie o swoje interesy objęte, jak się sugeruje, przemożnym oddziaływaniem rynku?

Być może należy się głębiej zastanowić nad tą zupełnie szczególną relacją dwu stron kontroli, bo wynika $\mathrm{z}$ tego, że dla przejmującego władzę nad młodymi wszechobecnego „rynku” zagrożenie stanowi właśnie to, co było/jest istotą szkoły. I co ma zostać również urynkowione. Bo, oczywiście, jeśli szkolnictwo wpisuje się w rynek, to powinno podlegać, przyznajmy, kontroli Państwowej Inspekcji Handlowej - która, rzecz jasna, powinna sprawdzać sprzedających (nauczycieli) - ich wagi i kasy fiskalne - a nie przynoszących pieniądze (zamiast swojej pracy) kupujących (uczniów, studentów, rodziców). Jeśli zatem sami nie podejmiemy tej kwestii, nikt tego za nas nie zrobi, a szczególnie nie ci, którzy zainteresowani są takim właśnie stanem rzeczy.

Dlatego konieczne staje się odwrócenie tak postawionego na głowie, jak to pokazaliśmy wyżej, zagadnienia kontroli zarówno jeśli chodzi o adresata działań kontrolnych, jak i jakość tych działań. Właściwa kontrola oznacza bowiem zarówno rezygnację z jej przerostów przybierających już postać elephantíasis poprzez dążenie do dokumentowania każdego kroku, jak i rezygnację z wyzbywania się tego, co stanowiąc nieodzowną reakcję zwrotną, uświadamiającą niedostatki wykształcenia i wynikające z tego kalectwo mentalne, tym samym pozwala na promowanie rozwoju. Autentycznego jakościowego rozwoju kształcenia, a nie ilościowego - na papierze i w statystykach.

W przekonaniu uczestników forów edukacyjnych TLiAM musi to być jednak związane także z całościowym myśleniem o systemie edukacji polonistycznej, co stanowi kolejną interesującą nas kwestię.

\section{CAŁOŚCIOWOŚĆ PROCESU EDUKACJI POLONISTYCZNEJ}

Na początek chcemy wyartykułować dwa oczekiwania niepopularne w środowisku akademickich dydaktyków.

Po pierwsze, skoro studia prawnicze i medyczne utrzymały swój status studiów pięcioletnich, uważamy, że powinno dotyczyć to także studiów polonistycznych, jeśli mają one spełniać swoją rolę przygotowania polonisty w pełnym tego słowa znaczeniu. Choćby dlatego, że jego rola w kształtowaniu zarówno twórczego myślenia jednostki, jak i w utrwalaniu tkanki społecznej jest nie do przecenienia. Nasze doświadczenia mówią nam, że student zarówno po trzech latach studiów licencjackich (zawarte w opublikowanym we wrze- 
śniu 2015 roku Programie rozwoju szkolnictwa wyższego i nauki na lata 2015$2030^{5}$ sugestie wydłużenia studiów I stopnia do czterech lat byłyby cenne, gdyby nie były nader mgliste i ulotne), podobnie jak po dwóch latach studiów uzupełniających, nie jest w stanie opanować tego samego materiału, co po pięciu. Szczególnie zaś ten, kto przychodzi na dwuletnie studia dające tytuł magistra filologii polskiej po trzech latach fizyki, dziennikarstwa czy muzykologii, ma niewielkie szanse, żeby nadrobić trzy poprzednie lata i rzeczywiście zostać magistrem „filologii polskiej” w znaczeniu takim, jakie to określenie miało, gdy dotyczyło absolwentów jednolitych studiów pięcioletnich. Za określeniem „magister” z pewnością nie stoi już dzisiaj zatem w sposób konieczny treść związana z kumulatywnością procesu kształcenia. I jednak o rzeczywistą treść terminu „magister” oznaczającego poszerzenie wiedzy, a nie zdobywanie jej „od zera”, upominamy się tutaj.

Ponadto, przypominając mimo wszystko, że w Niemczech niezależnie od przyjęcia systemu bolońskiego nie zrezygnowano z tradycyjnego („mistrzowskiego") podejścia do doktoratu, powrócę do studiów doktoranckich, które czynią go kolejnym etapem kształcenia, ale nie pierwszym etapem pracy naukowej. Oczywiście, w związku z ogólnym obniżeniem poziomu nauczania możemy uznać je w wielu przypadkach za niemal równoważnik ongisiejszego magisterium - i jeśli o to chodziło w systemie szkolnictwa, to cel został osiągnięty. Ale jeśli nie o to chodziło - wtedy należy zwrócić uwagę, że obecny system obsesyjnego zbierania punktów w ich ramach czyni te studia „wyścigiem szczurów” do stypendium naukowego, a samo studiowanie na III stopniu pozwala często po prostu uzyskać dostęp do bezpłatnego lektoratu języka angielskiego, bezpłatnego dostępu do lekarzy, zniżek komunikacyjnych, tak zwanych wejściówek i tak dalej (co zresztą w jeszcze powszechniejszym zakresie dotyczy studiów poprzednich stopni) - jednak nie do rozwoju naukowego. W przypadku poważnego traktowania tego stopnia studiów - i pojęcia „doktorat” - należałoby zatem zastanowić się nad przemyślaną, lecz szeroką, pomocą materialną dla kształconej dopiero na tym etapie prawdziwej elity intelektualnej społeczeństwa.

Po drugie, apelujemy o likwidację gimnazjum i powrót do dwupoziomowego szkolnictwa (podstawowe plus średnie). Ma to zmierzać do przywrócenia właściwego znaczenia także pojęciu e g z a m in d o j r z ało ści. W obecnym stanie ponadto - nie wspominając o zauważanych przez psychologów

5 Program rozwoju szkolnictwa wyższego i nauki na lata 2015-203o [online], Ministerstwo Nauki i Szkolnictwa Wyższego, [dostęp: 2015-10-o6]: <http://www.nauka.gov.pl/aktualnosci-ministerstwo/program-rozwoju-szkolnictwa-wyzszego-i-nauki-na-lata2015-2030.html>. 
negatywnych konsekwencjach w postaci rosnących na etapie przejścia między poziomami edukacyjnymi zaburzeniach i uzależnieniach (np. od narkotyków czy innych środków) - następuje tutaj pierwsze rozmycie odpowiedzialności za ciągłość i kumulatywność procesu dydaktycznego, podobnie jak dzieje się to w przypadku przejścia ze szkoły średniej na studia wyższe. Teoretycznie nauczyciel w liceum (a dotyczy to także nauczyciela akademickiego) może odpowiadać dziś za coś, co nie zostało właściwie zrobione wcześniej - nie przez niego.

Zarówno w przypadku przyjęcia, jak i nieprzyjęcia dwu powyższych postulatów (które w tym drugim przypadku będziemy ponawiać), aktualne pozostają kolejne, niepopularne z kolei w sferach rządowych i to pomimo że niezrealizowanie ich nie może być usprawiedliwione brakiem pieniędzy, skoro przez cały czas byliśmy zieloną wyspą, a obecnie z pewnością wychodzimy z kryzysu. Tym bardziej zaś nie może być tłumaczone niżem demograficznym, który pozostaje niezmiennie i nieustannie marnowaną szansą podwyższenia, a nie obniżania, standardu praktyki edukacyjnej.

Po trzecie zatem, w imię zgodności teorii z praktyką ciągle domagamy się zwiększenia godzin przeznaczonych na lekcje języka polskiego i na studia polonistyczne. W pierwszym przypadku w szkołach na poziomie podstawowym w zasadzie oczekujemy (i to nie kosztem poziomu rozszerzonego) co najmniej przywrócenia pierwotnie obowiązującej liczby godzin odpowiedniej do rangi przedmiotu, jakim jest język ojczysty (dziś polonista ma 12 godzin w cyklu kształcenia, to jest: I klasa - 4, II - 4, III - 4, natomiast przed reformą - 14, to jest odpowiednio: 5, 5 i 4 godziny, co stanowi wielką różnicę, szczególnie zważywszy, że w obowiązującej podstawie programowej mocniejszy nacisk położono na umiejętności, których wykształcenie zabiera znacznie więcej czasu niż poprzednio). Można by odnieść wrażenie, że dla odebranych godzin znaleziono, oczywiście, o wiele lepsze zastosowanie poprzez przekazanie ich znacznie bardziej podstawowym przedmiotom niż język ojczysty. Jakież to zatem przedmioty są bardziej podstawowe?

$\mathrm{Z}$ podobnego powodu oczekujemy większej liczby godzin na studiach polonistycznych, gdzie z godzin przeznaczonych na fachowe przygotowanie „wygospodarowano” znaczną liczbę zajęć na tak zwane specjalności lub specjalizacje zawodowe, wykłady fakultatywne, godziny wychowania fizycznego i tak dalej, a więc godziny luźno lub wcale niezwiązane z polonistyką w sensie ścisłym. Oznacza to okrojenie czasu przeznaczonego na rzetelne przygotowanie przede wszystkim polonisty, zanim - w dalszej kolejności - zostanie on dodatkowo kimś innym, to jest polonistą ze specjalizacją taką lub inną, rozwiniętym fizycznie i tak dalej. 
Można odnieść wrażenie, że system szkolnictwa testuje, na jak małym ogniu da się jeszcze coś upiec lub ile w tym samym czasie da się upiec pieczeni przy jednym ogniu (przygotowanie merytoryczne, przygotowanie zawodowe, rozwój sportu...). Ponieważ mamy do czynienia z niżem demograficznym, $z$ równym powodzeniem moglibyśmy zwrócić się do kobiet, by rodziły po pięciu miesiącach, nie po dziewięciu - oraz rodziły od razu trojaczki. Nie wiadomo jednak dlaczego, kiedy mówimy o fizycznych, zmysłowo dostępnych faktach, ich absurd dociera do nas łatwiej niż wtedy, gdy mówimy o rozwoju duchowym, intelektualnym, emocjonalnym i tak dalej.

Po czwarte, domagamy się zmniejszenia liczby uczniów na zajęciach z języka polskiego w celu umożliwienia zapisanego w podstawie programowej (pozostającej dziś z powodu zbyt dużej liczebności klas, jak to oceniają mgr Katarzyna Porembska i mgr Daniel Zych, jedynie zbiorem pobożnych życzeń) rzeczywiście zindywidualizowanego kontaktu z uczniem. Apelujemy o tworzenie małych grup na polonistykach, gdzie mimo to powinny działać mechanizmy umożliwiające rezygnowanie ze studentów przypadkowych, jeśli nie cynicznych - kierujących się na przykład taką motywacją, jak uzyskanie dzięki studiom (jakimkolwiek) przez dwa lub trzy lata darmowego lektoratu z języka angielskiego ułatwiającego późniejszą emigrację zarobkową.

Pod tym względem, jeśli chodzi o szkołę (podobnie, jak i pozostali nauczyciele biorący udział w dyskusji), mgr Joanna Zaremba przypomina, że teoretycznie dziś nauczyciel powinien mieć w pamięci stan wiedzy i umiejętności każdego podopiecznego (przynajmniej w zapisanych danych), a zatem zdiagnozować każdego ucznia i systematycznie sprawdzać przyrost konkretnych, rozłożonych na czynniki umiejętności. Pojawiły się nawet pomysły na stosowanie oceny opisowej na kolejnych etapach edukacyjnych (lub chociażby jej fragmentarycznej wersji w postaci opisu niedostatków edukacyjnych słabszych uczniów). Tymczasem, aby zrealizować same godziny pensum, polonista musi nie tylko pracować z pięcioma klasami (150-200 osób), ale i zabezpieczyć na ocenę i recenzję jednej pracy pisemnej miesięcznie (o ile to wystarczy) minimum 15 minut, czyli łącznie około 40-50 godzin. Dodajmy do tego kartkówki, sprawdziany i inne typy zadań, na które przeznaczamy tyle czasu, co na wspomnianą pracę. Oznacza to poza lekcjami około 25 godzin tygodniowo. Na lekcji natomiast jednemu uczniowi można poświęcić w tygodniu (jeśli nie liczyć czynności administracyjnych) od 4,5 do 6 minut (przy 30 do 40 uczniach w klasie). Autentyczny i bezpośredni kontakt $\mathrm{z}$ każdym $\mathrm{z}$ nich może być więc jedynie śladowy. Wiedzę, co prawda, może on (ewentualnie) jeszcze nabyć, pracując w domu, umiejętności nie opanuje bez pomocy i asysty nauczyciela, bez jego sensownej informacji zwrotnej. Rozwiązaniem zatem byłoby 
wprowadzenie jednej lub dwóch lekcji języka polskiego (ćwiczenia w mówieniu i pisaniu) z podziałem na grupy nie większe niż 10-15 osób. Nie jest bowiem jasne, dlaczego taki stan rzeczy udaje się osiągnąć, organizując lekcje języków obcych, a przy języku ojczystym już nie, choć przecież i jego znajomość nie jest zapisana w genach, zaś często - zapisana zostaje poza szkołą w sposób najfatalniejszy.

Podobnie wydaje się - na co zwraca uwagę prof. Teresa Kostkiewiczowa - że dostrzegane mankamenty kształcenia uniwersyteckiego w zakresie filologii polskiej niekoniecznie wynikają z wadliwości programów nauczania, ale raczej z warunków ich realizacji. Po pierwsze, chodzi o narzucane odgórnie limity godzinowe (np. 50\% wykładów), dyktowane nie merytorycznymi potrzebami i wymogami kształcenia, ale przede wszystkim ograniczeniami finansowymi. Po drugie, $\mathrm{z}$ tych samych powodów narzucane są wymogi dotyczące liczby osób w grupach studenckich, których wielkość (28-30 osób) uniemożliwia realizację programu i egzekwowanie zarówno wiedzy, jak i umiejętności. Zajęcia laboratoryjne na kierunkach przyrodniczych nie mogą przebiegać przy liczbie osób przekraczającej 12-15 uczestników, bo wtedy zdobycie niezbędnej praktyki byłoby niemożliwe. Tymczasem zajęcia na przykład $\mathrm{z}$ analizy utworu literackiego czy poetyki opisowej, które m a j ą właśnie charakter laboratoryjny i wymagają bezpośredniego kontaktu nauczyciela akademickiego $\mathrm{z}$ każdym uczestnikiem, prowadzone są w grupach 28-30-osobowych, co utrudnia, a nawet całkowicie uniemożliwia osiągnięcie właściwych efektów edukacyjnych i poznawczych.

Zwracamy ponadto uwagę, że jeśli chodzi o studia polonistyczne, to z jednej strony, z powodu odebrania możliwości wspomnianej zindywidualizowanej pracy na lekcjach (co powoduje, że w zasadzie dobra podstawa programowa pozostaje tylko martwym zapisem), z drugiej strony z powodu nie tylko braku egzaminów przy przyjmowaniu na studia, ale i w konsekwencji daleko posuniętej fasadowości egzaminów szkolnych, szczególnie maturalnego, na polonistykę przychodzą (w swej masie) ludzie coraz gorzej przygotowani, z poważnymi brakami językowymi (leksyka, ortografia, gramatyka, frazeologia - łatwiej tu, niestety, wyliczać problemy, niż wskazać mocne strony) i merytorycznymi (wynikającymi z ograniczonego ilościowo i objętościowo kontaktu z lekturami oraz słowem pisanym w ogóle, a z poprawnym słowem mówionym w szczególności). Jest tajemnicą poliszynela, że w istocie na polonistyce trzeba by w wielu przypadkach uczyć podstaw - i rzeczywiście należy to czynić, skoro nie udało się (nie było możliwości) zrobienia tego wcześniej. Dlatego też konieczne staje się - na filologii polskiej - wprowadzenie zajęć „wyrównawczych" z podstawowych obszarów kształcenia polonistycznego, na 
których realizację potrzebne są jednak dodatkowe godziny, ponieważ służyć ma to nie poszerzaniu wiedzy wyniesionej ze szkoły, ale nadrabianiu zaległości.

To ostatnie zresztą tym wyraźniej wskazuje, że na kształceniu nie da się oszczędzać: zaniedbania z poprzednich lat nauki same się nie naprawią - powrócą prześmiewczym echem na wyższych poziomach edukacji, gdzie ich usunięcie jest trudniejsze niż niedopuszczanie do ich powstania.

Ten ostatni problem kompromituje, niestety, obecny system szkolnictwa. I nie pomogą tu jedynie wezwania do tego, by każdy „robił swoje” na każdym z poziomów, bo na to właśnie za dużo jest osób w klasie/grupach studenckich, brakuje czasu na lekcjach/konwersatoriach których liczba została w trakcie kolejnych reform ograniczona, i brakuje go poza nimi - zabiera go za to bez ograniczeń zachłanna biurokracja lub niepolonistyczne obszary. Wyrażając nie tylko własną opinię, prof. Teresa Kostkiewiczowa stwierdza zatem, że trzeba się domagać przerwanie tego łańcucha niewydolności i braków dzięki szybkim działaniom władz oświatowych, które powinny dołożyć wszelkich starań, aby stworzyć nauczającym optymalne warunki realizacji ich celów edukacyjnych.

Dlatego też jesteśmy wbrew wszelkim nieciągłościom, jakie zostały narzucone szkolnictwu - za przywróceniem całościowego myślenia o nim jako o systemie - bez izolowania poszczególnych jego etapów. Zapewne punktem wyjścia do uzyskania takiego stanu jest przede wszystkim kontakt obu ministerstw oraz ministerstw i środowisk nauczycielskich tudzież akademickich - a zatem konsultacje raczej kompetentne i pogłębione, niż szerokie.

Potrzebę takiego całościowego ujęcia, związaną z tym, że dyskusja o zmianach i przyszłości edukacji polonistycznej nie powinna być prowadzona w odniesieniu do tylko jednego czy dwu poziomów kształcenia, lecz każda korekta w programie winna być skorelowana $z$ systemem, prof. Tomasz Chachulski uzasadnia tym, że kolejne etapy edukacji mają kończyć się (także na studiach doktoranckich) osiągnięciem określonych i łączących się ze sobą celów, jeśli chodzi o wiedzę, umiejętności oraz kompetencje społeczne ucznia i studenta. Jeśli zaś chodzi o nauczyciela, to kształcąc uczniów, powinien on mieć w pamięci zarówno etapy wcześniejsze, jak i późniejsze. Wreszcie konsekwencja taka musi mieć miejsce, jeśli chodzi o przyszłego badacza, zaangażowanego w kształcenie nauczycieli, a także w nowe wizje szkolnictwa.

W takim duchu rzecz ujmując, przedstawiamy tu naszą diagnozę i oczekiwania dotyczące takiego całościowego systemu, zaznaczając, że przy nacisku położonym zarówno na rozwój indywidualnych zdolności twórczych, jak i na kształtowanie i utrwalanie tkanki społecznej jesteśmy za polonistyką otwartą tyleż na wewnętrzne, ileż na zewnętrzne zróżnicowanie. Tym bardziej 
że tylko takie otwarcie pozwala jej - ponieważ ma ona pod tym względem znacznie rozleglejsze zobowiązania niż jakikolwiek inny przedmiot - realizować także wiele zadań wychowawczych związanych choćby z zapobieganiem ksenofobii czy wykluczeniom ze względu na status ekonomiczny, poglądy, pochodzenie etniczne, wyznanie, orientację seksualną bądź inne odmienności, a zwłaszcza z przekazywaniem wzorców osobowych i wartości etycznych, poznawczych czy estetycznych. Tak więc nasza wizja nastawiona jest na umiejętne łączenie tożsamościowej opcji filologii narodowej i dającej wielostronny obraz odwołujący się do inności, ale i wspólnoty czy uniwersalności - właściwy dla opcji porównawczej.

Jak zaś przypomina prof. Zofia Budrewicz, komparatystyczne zobowiązania polonistyki mają dawne korzenie: ta koncepcja przywoływana już od 1905 roku, weszła w Polsce do programów po 1932 roku. Nie jest to zatem wynalazek nowy. Komparatystyka powinna od początku edukacji wprowadzać elementy podejścia wielokulturowego i międzykulturowego, które pozwalają na wyeliminowanie opcji egocentrycznej - przy zachowaniu zarazem tożsamości i oryginalności. Być może należałoby to połączenie przedstawić i rozwinąć w alternatywnym, a przydatnym dla nauczycieli mniej twórczych i zdolnych do kierowania się jedynie ogólnikowymi wskazówkami dokumencie. Powinien on być znacznie szerszy niż skromna podstawa programowa, mógłby też pełnić funkcję prawdziwego przewodnika, pokazującego współdziałanie polonistyki i komparatystyki - tej drugiej zaś przede wszystkim jako metody poznawczej i modelu interpretacji kultury realizowanego i upowszechnianego na wszystkich etapach kształcenia.

\section{A.Szkoła podstawowa a treści polonistyczne i komparatystyczne}

Kluczowa dla naszej propozycji całościowego ujęcia kształcenia jest wyartykułowana przez prof. Teresę Kostkiewiczową obserwacja, że jako zasadniczy moment inicjacji w kulturę oraz przygotowania człowieka do komunikacji interpersonalnej czy publicznej (język mediów, polityki, administracji itd.) zaniedbana dziś została szkoła podstawowa, a zaniedbanie to skutkuje na dalszych etapach kształcenia ciężkimi przypadkami kalectwa myślowego i językowego.

Bez odniesienia do konkretów być może nie zdamy sobie do końca sprawy, z jakiej skali i jak głęboko sięgającym zjawiskiem mamy do czynienia, zatem ze smutkiem wyżej podpisana przywoła przykłady deformacji języka polskiego pochodzące nawet z prac uczniów przystępujących do Olimpiady Literatury i Języka Polskiego, zaznaczając jednakże, iż ostatecznie podobne ilustracje rozpadu sensu w użyciach rodzimego języka znaleźć można nawet 
w wypowiedziach studentów polonistyki oraz pokrewnych kierunków, takich jak kulturoznawstwo czy dziennikarstwo ${ }^{6}$.

Nasz podstawowy postulat dotyczy zatem wprowadzenia i egzekwowania rzetelnej, zarazem drobiazgowej i szerokiej pracy nad językiem, przejawiającej się w sferze wpajania zasad posługiwania się nim, ale przede wszystkim w nieustannym kształceniu praktycznego jego użytkowania (przy użyciu szerokiego zasobu leksyki, której być może należałoby poświęcić specjalną uwagę, i przy respektowaniu zasad gramatycznych, ortograficznych i in.). Oznacza to wysiłek włożony zarówno w rozwijanie umiejętności pisania (na tym poziomie

6 Prace olimpijczyków dopuszczanych do etapu okręgowego - a więc uczniów teoretycznie pozytywnie wyróżniających się w masie "niezainteresowanych” - bywają wątpliwej jakości skarbnicą wypowiedzeń w znacznej mierze bezsensownych (np. „Zhierarchizowanie rodzajów relacji słowa pisanego z dźwiękiem ułatwia interpretację wydźwięków kulturowych, dlatego w pracy nad nimi pozwoliłem sobie stworzyć swoistą klasyfikację"), zdań niekompletnych i wadliwie skonstruowanych, zawierających zupełnie zdumiewające sformułowania (np.: „Z muzyki ewoluowały konsekutywne formy twórczości”; „zanim ludzie zaczęli inscenizować rzeczywistość w formie teatru, nadawać formy swojej wyobraźni w postaci płaszczyznowej (malarstwa)") lub zbijające z tropu użycia słów (np. „referencje do Wenus”; „Led Zeppelin referuje do Valhalli”; „domyślne rozważanie na temat nimfy”; „w warstwie tekstowej konektuje to z chaosem”; „rzeczony Tolkien... stanowił sugestię do twórczości”) etc. W recenzji pracy zawierającej te sformułowania, pomimo że autor nosił polskie nazwisko, pozwoliłam sobie wyrazić przypuszczenie, że musi być cudzoziemcem. Niestety, takie przypadki to nie incydenty. Niepoprawność i idąca za nią niezrozumiałość wypowiedzi staje się raczej (negatywną) normą. Oto inne przykłady: „podczas chęci”, „podczas apatii”, „Wokulski jest nawiązaniem” i „przyodziewa atrybuty świata wyższego”, działania „odzwierciedlają schemat bohatera hymnu”, „sfera liryczna Lao Che jest zawsze w klimatycznej aranżacji”; „zjawisko intertekstualności łączy dzieła różnorodnej formy”. Do tego dochodzą, oczywiście, jeszcze „zwykłe”, standardowe błędy (gramatyczne, interpunkcyjne, frazeologiczne etc.). Kolejne przykłady: Ludwik Kropiński „chciał obudzić w Polkach rodowitą mowę”; adresat „musi twardo prezentować swoją atmosferę psychiczną”; „stosunek nadawcy z liczniejszym gronem nadawców nie pokrywa się - jest odmienny”; od adresata zależy „ujęcie stylistyczne listu czy formalność”; cechy dobrego epistolografa „rozbijają się na milion indywidualnych warunków twórczych”, a „Inne własności języka autora dotyczącej cech listu, związane z życiem potocznym, to elipsy, zasady budowy zdań wewnętrznych czy powiązań międzyzdaniowych". I jeszcze jedna egzemplifikacja: „styl i słownictwo «listów poetyckich» nie mogą być pisane przez apostoła Pawła. Wniosek ten budził kolejne sprzeczności w tej kwestii”; „listy romansowe do matki”, „korespondencje utrzymane w świetle towianizmu”; „absorbuje epistolograf romantyczny do Krasińskiego”, „kawałek papieru, który pochłania suche wyrazy”; „kawałek materiału piśmiennego”; „Konopnicka obarczała sama siebie gorzkimi i surowymi uwagami”; „Szczerość wielkiej poetki kształtuje się na podstawie jej uprzedzeń”; „Szowinizm, jakim cechuje się poetka, najczęściej wynikał z kuchni lokalnej, która nie ma porównania z tradycyjnym polskim jedzeniem". 
- tekstów prostych, przede wszystkim zaś użytkowych, takich jak: podania, wnioski, sprawozdania etc.), jak i mówienia, w tym pokonywania samego lęku przed wypowiadaniem się. Sądzimy, że łącznikiem między jedną a drugą umiejętnością mogłoby być też głośne czytanie (ze zrozumieniem) na lekcji, które - poszerzone o umiejętność recytacji - pojawiałoby się także sukcesywnie na kolejnych poziomach kształcenia. Należałaby je też potraktować jako wstęp do koniecznego wyrabiania nawyku czytania utworów literackich i innych tekstów (np. prasowych).

Ponieważ realizm każe nam zwrócić uwagę, iż większość zapracowanych rodziców nie ma czasu (a część - umiejętności lub chęci), by zajmować się edukacją dziecka w domu, musimy domagać się czegoś więcej niż językowego kształcenia w ponaddwudziestoosobowej klasie, dodatkowo ogromnie utrudnionego przez współczesną kulturę obrazkową oraz media elektroniczne skoncentrowane na grze jako najbardziej atrakcyjnej narracji, a także przez kulturę masową nastawioną na eksces, w tym eksces językowy. Już na tym etapie zatem pojawia się konieczność tworzenia dla tego celu grup zbliżonych liczebnie do tych, które służą nauce języka obcego. Umożliwi to indywidualizację nauczania. Nie jest bowiem przesadą stwierdzenie, że w tej chwili znaczna część (szczególnie młodych) Polaków, którzy niewątpliwie formalnie przeszli przez szkołę podstawową, posługuje się językiem polskim jak obcym, a inna niemała część - prawie wyłącznie językiem wulgaryzmów, przy czym wykształcenie wyższe nie stanowi już dziś w tej mierze żadnej bariery - ani psychologicznej, ani obyczajowej.

Teksty dla kształcenia językowego na tym etapie powinny przy tym pochodzić zarówno z obszaru codziennego doświadczenia, jak i z literatury pozwalającej obserwować bardziej rozwinięte i wysublimowane możliwości języka, ale tutaj jeszcze udział komparatystyki byłby dość skromny.

\section{B. Gimnazjum a polonistyka i komparatystyka}

Nadal za punkt wyjścia trzeba tu uznać doskonalenie języka w ogóle - dokonywane poprzez pisanie, czytanie (także czytanie głośne i recytacje) oraz mówienie. W tym momencie jednak już musi wyraziście zostać wyartykułowany nie tylko wyższy poziom wypowiedzi (np. rozprawka jako problematyzacja treści), ale i kształtowanie praktycznej umiejętności czytania i rozumienia utworów literackich i kulturowych w ogóle.

Konieczna jest tu zatem obecność konkretnych utworów z polskiego kanonu literackiego (mgr Katarzyna Porembska i mgr Daniel Zych oraz inni nauczyciele uparcie przy tym podkreślają, że obowiązkowych lektur jest stanowczo za mało), a także podstaw wiedzy literacko-kulturowej, w tym (bez zbyt- 
niej abstrakcji, jednak i bez uchylania się od uchwycenia ich sensu) podstawowych pojęć, takich jak sztuka, kultura, pisarz, artysta oraz przynajmniej (na przykładzie utworów) najskromniejszych zarysów ujęcia historycznoliterackiego. Stwierdzić bowiem można dziś zatrważające zjawisko coraz mniejszej wiedzy na tematy związane z kulturą, historią, literaturą, sztuką, co pozwala opowiadać nauczycielom smutne dowcipy związane $\mathrm{z}$ faktem, że nie wszystko można wygooglować.

Natomiast w zakresie treści potrzebne jest na tym etapie przede wszystkim budowanie rozeznania tożsamości narodowej w oparciu o literaturę/kulturę polską - przy tym jednak ze wskazaniem (w ramach „komparatystyki wewnętrznej”) na jej własne zróżnicowanie tyleż historyczne, to jest wertykalne, co przestrzenne, to jest horyzontalne. Niemniej konieczne jest tu także wprowadzanie pierwszych elementów komparatystyki „zewnętrznej” w postaci literackiej i mitycznej tradycji od Gilgamesza przez antyk grecko-rzymski po Biblię.

Zasadne i celowe byłoby też, wedle dyskutantów, utrzymanie na tym poziomie elementów interpretacji porównawczej (z literaturą w punkcie wyjścia), odwołującej się do opisu specyfiki różnych tworzyw artystycznych i medialnych. Przy tym obszar zagadnień programowych i tekstów związanych z kulturą mediów szczególnie powinien eksponować tu pragmatykę pozwalającą na rozumienie tego, co związane jest $\mathrm{z}$ wartościowaniem mediów, etyką i estetyką komunikacji, czy wyjaśnianiem kwestii tożsamości w sieci. W ramach aktywności porównawczej można ponadto sfunkcjonalizować wiedzę o mediach tak, by służyła ona też poznawaniu literatury i rozwojowi kompetencji literackich.

Jak podpowiada dr Mirosław Gołuński, duża popularność nowych gatunków literackich związanych $\mathrm{z}$ medium internetowym (takich jak fan fiction, blog, a ogólnie - e-literatura), w ramach których młodzi ludzie próbują swoich sił, zarówno reagując na zastane teksty kultury (popularne blogi recenzenckie), jak i wkraczając samodzielnie na obszary twórczego jej uprawiania (fan fiction), sprawia, że szkoła może potencjał ten wykorzystać. Znakomita większość uczniów ma dostęp do internetu (w domu lub w szkole), nie ma więc technicznych przeszkód, by nauczyciele poloniści zakładali wspólne blogi literackie, na których uczniowie pisaliby na przykład tak zwane fanfiki, czyli alternatywne wersje losów lekturowych bohaterów (Lalki Bolesława Prusa czy Pana Tadeusza Adama Mickiewicza), blogi recenzenckie - poświęcone ulubionym czy właśnie czytanym lekturom młodzieży, a nawet prowadzone w wielu szkołach e-gazetki. Zważywszy na skandalicznie niski merytoryczny i językowy poziom nieweryfikowanej przez nikogo twórczości młodych ludzi w internecie, by- 
łaby to okazja, by dzięki powszechnej dostępności medium, bez dodatkowych kosztów oraz dzięki wykorzystaniu dydaktycznej wyobraźni nauczyciela, a zarazem pobudzając kreatywność uczniów, poszerzyć językowe i interpretacyjne instrumentarium opisu świata przez tych ostatnich. Nie ma też przeszkód, by tego typu działania były rozwijane również w szkołach ponadgimnazjalnych.

\section{Liceum a polonistyka i komparatystyka}

Przy kierowaniu w dalszym ciągu uwagi na język (w tym na głośne czytanie czy recytację, doskonalenie rozprawki, przejście ku esejowi czy recenzji) celowe wydaje się tu nasilenie kontrapunktowego spojrzenia, zmierzającego do uczenia wydobywania podobieństw i różnic:

a) Dodając do lektur gimnazjalnych kolejne utwory/teksty z literatury polskiej, jednocześnie wprowadzić można przykłady z literatury europejskiej, pozwalające na porównania typu: Prus jako polski Balzak; Horacy a Kochanowski; Antygona Sofoklesa i Antygona w Nowym Jorku Janusza Głowackiego. To także czas na zapoznanie uczniów z motywami czy tematami mitycznymi, pokazanie ich wariantowych realizacji w różnych czasach i miejscach. Ciekawe może okazać się również eksponowanie kontekstów postkolonialnych i tak zwanej antropologii różnic w opisie i wartościowaniu treści literacko-kulturowych zawartych na przykład w Potopie, Tomku w krainie kangurów czy W pustyni i w puszczy. Wreszcie literatura wysoka (kanon) może zostać porównana z jej realizacjami (adaptacjami) popularnymi (kultura masowa), a wiedza o kulturze (występująca jako odrębny przedmiot) wykorzystana być może do kontekstualizacji zagadnień literaturoznawczych (integracja treści programowych).

b) Utwory polskie i obce oraz motywy mityczne stanowić mogą z kolei podstawę sięgania do innych sztuk: filmu, plastyki, muzyki, teatru (klasycznego i awangardowego) oraz sztuki właściwej dla tradycyjnych i nowych mediów. Czytanie i opis tekstów kultury audiowizualnej w perspektywie komparatystyki intermedialnej może zaś służyć odsłanianiu głównych zjawisk związanych $\mathrm{z}$ antropologicznymi aspektami, pokazać cechy swoistego „języka” literatury tworzonej w środowisku nośników elektronicznych i cyfrowych (tu np. pojawiają się kwestie: „literatura w sieci” i „literatura sieci”).

c) Utwory polskie i obce oraz motywy mityczne stanowić mogą wreszcie podstawę (proponowanego przez dr Annę Ślósarz) wiązania tekstów różnych mediów w tak zwane moduły tematyczne, nadbudowane nad dziełami literackimi, odgrywającymi rolę podstawową. Głośne odczytanie w klasie całego tekstu (np. Wesela) i zestawienie go ze wspólnie obejrzaną filmową adaptacją, tekstem non-fiction, współczesnym reportażem lub wyszukanym przez każdego ucznia wierszem, obrazem, plakatem, piosenką, fotografią czy reklamą, 
wpisem zamieszczonym na forum społecznościowym służyć mogą formowaniu wzoru czytania kontekstualnego, problematyzowaniu tekstu, integracji symbolicznych makrostruktur, eksponowaniu cech języka, znaczeniotwórczej roli tworzyw i gatunków poszczególnych mediów (zwłaszcza cyfrowych, dziś odgrywających największą rolę kulturotwórczą), a zarazem - reinterpretacji i aktualizacji narodowej klasyki, a także odnajdywaniu w niej wspólnej przestrzeni kulturowych reprezentacji oraz modeli zbiorowej tożsamości.

d) W perspektywie porównawczej może też znaleźć tu swoje miejsce uczenie analizy i interpretacji literatury hipertekstowej (na prostych przykładach, np. Bloku Sławomira Shutego czy Końca świata według Emeryka Radosława Nowakowskiego), dokonujące się przy użyciu tradycyjnego warsztatu interpretacyjnego stosowanego w przypadku „klasycznych” narracji.

Ponieważ repetitio est mater studiorum, intencją naszą byłoby stopniowe i przemyślane wprowadzanie utworów literackich tak, aby mogły one być nieustannie aktualizowane w kolejnych, poszerzanych o nowe elementy ujęciach, kontekstach, powiązaniach - czytane całościowo, systematycznie, ale i wielokrotnie, pod różnym kątem. Byłaby to też próba walki z powszechną na lekcjach języka polskiego praktyką nieczytania/niedoczytywania, która staje się (mówili o tym mgr Porębska i mgr Zych) najważniejszą pseudoumiejętnością wynoszoną z kolejnych etapów kształcenia przez młodych ludzi, przyzwyczajanych do tego, że można dobrze zdać egzamin gimnazjalny czy maturalny, nie znając lektur (a w najlepszym razie znając tzw. bryki, gdyż nawet dobrych opracowań brak).

Jak widać zatem, nasze postrzeganie procesu kształcenia przechodzi od języka (nigdy później zresztą nie tracimy go z oczu) do literatury i innych tekstów kultury, a od myślenia bardziej jednorodnego do bardziej kontrapunktowego. Chciałabym jednak dodać jeszcze jedną kwestię, mianowicie konteksty języka polskiego w szkołach. Począwszy od szkoły podstawowej należałoby myśleć o tym (utraconym w toku reform) kontekście, jaki stanowią przedmioty artystyczne: muzyka czy plastyka, a od liceum o takim, jaki stanowi filozofia (nie historia filozofii) jako nauka myślenia. Pod tym względem zgodni są ze sobą tak nauczyciele (wyartykułowała to mgr Anna Nakielska-Kowalska), jak i wykładowcy wyższych uczelni (prof. Tadeusz Sławek, prof. Magdalena Saganiak, a także wyżej podpisana).

\section{Studia polonistyczne}

Pozostaje jeszcze rzut oka na studia polonistyczne, jak już sygnalizowałam - niewydolne z powodu dwustopniowości, która uniemożliwia szersze i pogłębione ujęcie historycznoliterackie. Ale pojawia się też kwestia filologii polskiej 
jako modelu studiów, których celem jest zagwarantowanie absolwentom podstawowego wykształcenia humanistycznego, zapewniającego podejmowanie pracy w różnych dziedzinach życia społecznego i kulturalnego, w tym również w szkole - a więc kwestia traktowania studiów jako studiów, a nie szkoły zawodowej, co znaczy właściwie: „szkółki” dającej wąskie przygotowanie do domniemanych aktualnych wymagań rynku, często zresztą zwodniczych i krótkotrwałych.

Myślę, że zacząć tu trzeba od świadomości kandydatów na studia polonistyczne, którzy, jak niemal definicyjnie ujmuje to prof. Teresa Kostkiewiczowa, muszą sobie zdawać sprawę, że - zgodnie z etymologicznym znaczeniem nazwy kierunku - podstawową aktywnością, której się od nich oczekuje, jest lektura dzieł i formułowanie przemyślanych, wspartych zdobywaną wiedzą teoretycznoliteracką $\mathrm{i}$ historyczną wypowiedzi na ich temat $\mathrm{w}$ formie pisemnej i ustnej. Na studiach wymogi te powinny być egzekwowane rygorystycznie. Pozostaje natomiast kwestią do rozważenia, czy domagać się przywrócenia egzaminu wstępnego, który taki rygor uświadomi - dziś niekoniecznie świadomym go studentom.

Drugą istotną kwestią są programy. Przyjmujemy (wyartykułowała to prof. Kostkiewiczowa), że poza głównymi nurtami studiów polonistycznych powinny być proponowane studentom zajęcia fakultatywne (np. wiedza o kulturze, komparatystyka, problemy antropologii - tu otwiera się pole dla pomysłowości i inicjatyw wykładowców, odpowiadających na zainteresowania studentów i w zgodzie z... „duchem czasu”), zajęcia uzupełniające (np. z historii, języki obce) i specjalizacyjne (np. nauczycielskie, edytorsko-wydawnicze). Student pozostawałby zobowiązany do realizacji określonej porcji zajęć fakultatywnych lub uzupełniających (np. 30 godzin na każdym roku) tak, by ich wybór należał tylko do niego i był dyktowany osobistymi zainteresowaniami i potrzebami intelektualnymi. Podobnie wyglądać musi wybór specjalizacji oraz seminarium licencjackiego lub magisterskiego przy obecnym trybie, bądź na przedostatnim roku studiów - magisterskiego (jeśli myśleć w perspektywie przywrócenia kształcenia w trybie pięcioletnim). Powinien być to zawsze wybór podyktowany konkretnymi zainteresowaniami i dotyczący sprecyzowanej problematyki literackiej, lingwistycznej lub pedagogiczno-metodycznej.

Nie zmienia to jednak standardowych oczekiwań. Ograniczając w tym miejscu kwestię programu nauczania językowego (którego opracowanie leży w kompetencji specjalistów lingwistów) jedynie do położenia nacisku na starania o możliwie jak najdalej idącą korelację dwu nurtów i wykorzystywanie wiedzy z jednej dziedziny (wiedza o literaturze) w drugiej (językoznawstwo) bądź odwrotnie (co jest do zrealizowania - z jednej strony na przykład na zajęciach 
z poetyki, z drugiej zaś w związku z historią i teorią języka) - prof. Teresa Kostkiewiczowa zatrzymuje się przy sprawie minimum programowego w zakresie nauki o literaturze, wyodrębniając dwa obszary nauczania. Pierwszy - to teoria literatury, obejmująca takie przedmioty, jak wstęp do nauki o literaturze, analiza utworu literackiego, poetyka, teorie literatury i metodologie badań literackich. Drugi - to historycznie uporządkowana wiedza o literaturze, o literackim dorobku różnych epok kulturowych w obrębie literatury narodowej i literatur obcojęzycznych.

Zaznacza też ona, że niezbywalne w naukach humanistycznych podejście porównawcze (różnych dzieł, twórczości różnych pisarzy, różnych epok literatury narodowej) powinno być wzbogacane komparatystycznym spojrzeniem, wprowadzającym w pole uwagi wybitne dzieła piśmiennictwa światowego różnych epok. Może to przebiegać albo w ramach wykładów i seminariów z historii literatury, albo na oddzielnych zajęciach, dotyczących na przykład arcydzieł literatury, czy na (wybieranych przez studentów) spotkaniach poświęconych istotnym problemom literatury jednego kręgu kulturowego (np. śródziemnomorskiego, północnoeuropejskiego, iberyjskiego etc.). Warunkiem realizacji minimum programowego i osiągnięcia przez studiujących niezbędnej wiedzy w tym zakresie jest podjęcie przez nich - pod opieką wykładowców - samodzielnej, rozumiejącej lektury dzieł literatury polskiej tworzących jej podstawowy kanon i - w określonym zakresie - obcej (europejskiej i światowej). Nabycie umiejętności takiej lektury dzieł, która jest w stanie odsłonić wartości (artystyczne, myślowe, ideowe) i rozpoznawać sposoby ich literackiej artykulacji, stanowi tu podstawowy cel, którego osiągnięcie staje się też warunkiem wykształcenia zdolności przenoszenia tej wiedzy do nauczania szkolnego - i na ten aspekt ciągłości kształcenia warto zwrócić uwagę.

Jednocześnie w związku z zapotrzebowaniem szkolnym, ujawniającym się w przedstawionym przez nas projekcie, trzeba zastanowić się i nad wprowadzeniem możliwości nabycia na polonistyce innych kompetencji komparatystycznych - związanych ze sztukami, mediami i tak dalej, aczkolwiek działanie takie zarazem powinno być wyważone, aby uniknąć przy tym hybrydyzacji polonistyki.

Rzecz znamienna jednak, że ten problem hybrydyzacji obserwujemy dzisiaj bynajmniej nie w związku z orientacją studiów na komparatystyczne zobowiązania wobec wcześniejszych etapów kształcenia, ale w związku z ich orientacją na rynek. Prof. Marek Stanisz uznaje, że stanowi to efekt niedoinwestowania, powodującego rosnący chaos akademickiego kształcenia na kierunku filologia polska. Przedmioty tak zwane fakultatywne i specjalizacyjne wymuszone zostają przez odgórne rozporządzenia, domagające się ich udziału w co 
najmniej 30\% ogólnej liczby godzin, a dokonuje się to kosztem przedmiotów kierunkowych. W programach studiów polonistycznych pojawia się w ten sposób sporo przedmiotów i specjalizacji przypadkowych, których główną zaletą są atrakcyjne nazwy i status przedmiotów fakultatywnych, ale ich zakres pozostaje bliżej nieokreślony. Specjalizacje na polonistyce (dr Dorota Utracka przywołuje takie, jak reklama, media, PR, audiowizualność, komunikacja społeczna, projektowanie komunikacji (sic!), antropologia - od mody do kulinariów, a nawet turystyka kulturowa) powodują, że absolwenci, co zrozumiałe, nie są w stanie zdobyć kompetencji kierunkowych i kluczowych, jakie firmuje, lub przynajmniej powinna firmować, nazwa „filologia polska” (a dyplomy z takim zapisem otrzymuje absolwent). Nie zdobywają oni zatem elementarnej wiedzy i umiejętności ani polonistycznych, ani też innych, bo z kolei treści specjalizacyjne poznają powierzchownie i w celach czysto użytkowych. Tworzy się w ten sposób w wielu przypadkach jedynie fikcję kompletności i większego pragmatyzmu studiów polonistycznych, natomiast w istocie skutkuje to utratą ich tożsamości i powierzchownością, a nawet pozornością wiedzy w każdym z tych obszarów.

Postulaty, które w związku z tym przedstawia prof. Marek Stanisz, brzmią następująco: należy zwiększyć tak zwany współczynnik kosztochłonności kierunku filologia polska - przynajmniej do poziomu filologii obcych (obecnie współczynnik kosztochłonności dla filologii polskiej jest na najniższym poziomie, to jest: 1, podczas gdy współczynnik kosztochłonności filologii obcych wynosi 1,5); obniżyć liczebność grup studenckich (stanie się to możliwe po zwiększeniu dotacji stacjonarnej na studiach polonistycznych); zwiększyć o 10-20\% liczbę godzin przewidzianych na kształcenie polonistyczne (tzn. konkretnie - na przedmioty kierunkowe).

To ostatnie związane jest $\mathrm{z}$ faktem, że choć teoretycznie minimalna ogólna liczba godzin na polonistyce nie zmniejszyła się od pewnego czasu (180o na I stopniu i 800 na II stopniu), to jednak praktycznie ich liczba na fachowe przygotowanie polonisty zmniejszyła się wydatnie. I to nie tylko o wspomniane obligatoryjne $30 \%$ przeznaczane często na owe atrakcyjne marketingowo nazwy (bardziej niż treści), ale i, na przykład ostatnio, dzięki zabraniu kolejnych 60 godzin na zajęcia wychowania fizycznego. A dzieje się to nie w warunkach poprawiającego się przygotowania na studia polonistyczne, ale w warunkach katastrofalnego niemal pogarszania się poziomu przychodzących na nie studentów. A także w obliczu dramatycznie pogłębiającej się niemożności partycypacji w procesie dydaktycznym, wynikającej z kierującego studentami przymusu ekonomicznego, który zmusza ich do podejmowania pracy zarobkowej w trakcie studiów. Dodajmy: także w trakcie studiów doktoranckich. 
Trzecim istotnym problemem domagającym się tu podjęcia, jest problem kadry naukowej. Jeszcze raz odwołam się do diagnozy prof. Marka Stanisza. Czyni on obowiązujący na uczelniach punktowy system mierzenia jakości pracy naukowo-dydaktycznej odpowiedzialnym za wiele istotnych (w dużej części negatywnych) zmian w funkcjonowaniu nauki w Polsce. Skutkuje to między innymi powszechnie obowiązującym dyktatem ilości (zamiast jakości) oraz szybkości „produkcji” zamiast pogłębienia treści prac naukowych. System przyznawania grantów badawczych przez takie instytucje jak Narodowe Centrum Nauki czy Narodowy Program Rozwoju Humanistyki staje sięźródłem ogromnego marnotrawstwa kapitału intelektualnego, a przede wszystkim czasu pracowników uczelni wyższych (wnioski o finansowanie projektów badawczych przygotowywane są zwykle przez kilka tygodni lub miesięcy, uczestniczą w tym często całe zespoły badawcze, tymczasem procent projektów badawczych kierowanych do finansowania jest stosunkowo niewielki). System promuje więc raczej tych, którzy traktują swój zawód instrumentalnie, tym bardziej że nie ma parametrów pomiaru wielu form aktywności zawodowej, w tym dydaktycznej.

Rezultatem przedstawionych w tych opisach negatywnych tendencji dzisiejszego systemu szkolnictwa jest spadek motywacji do pracy wielu polonistów zarówno na uczelniach, jak w szkołach. Być może jest to również ważny powód do nawiązy wania ściślejszej współpracy między środowiskami - w celu przeciwstawienia się opisanemu podważaniu tożsamości szkolnictwa, polonistyki, a także wszystkich podmiotów uczestniczących w procesie edukacyjnym.

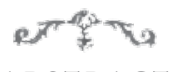

A B S T R A C T

Diagnoses and Proposals of III AND IV TLiAM

- Little Education Forum

The article constitutes a structured and systematic record of the discussions and the work of more than twenty people representing various centers in the country and different levels of education, who undertook major problems causing the failure of this system - primarily, though not exclusively - in the field of Polonistic education. The first part indicates the pathologies of attitudes on all sides of the educational process resulting from the fact that this process is treated as a market phenomenon, including the reversal of the relationship of control, which multilaterally touches teachers / lecturers at the university (as sellers), while students (customers) remain free of it. At the same time a fundamental principle is forgotten, namely that the proper price for knowledge and skills is not money (or points as its academic equivalent), but 
work (and a creative collaboration of different parties, rather than a demanding attitude entities being educated and fruitless squandering of forces regarding empty, bureaucratic activities of educators). The request to restore the identity of education and to free it from a net of bureaucracy is connected to the task of restoring the importance of Polonistic content. In the second part the debaters recognize a need to assign proper roles to exams (and especially to matriculation) largely facade in its current form according to the diagnosis; they also point to ways to once again assign examinations with an appropriate rank. In the third part they demand thinking about school/university in terms of communicating vessels, and show an example of such thinking connecting Polonistic and comparative perspective.

\section{KEYWORDS}

school system, Polonistic education, Polish studies, comparative perspective in Polonistic education 